\title{
Are recent changes in sediment manganese sequestration in the euxinic basins of the Baltic Sea linked to the expansion of hypoxia?
}

\author{
C. Lenz ${ }^{1}$, T. Jilbert ${ }^{2}$, D.J. Conley ${ }^{3}$, M. Wolthers ${ }^{3}$, and C.P. Slomp ${ }^{3}$ \\ ${ }^{1}$ Department of Geology, Lund University, Sölvegatan 12, 22362 Lund, Sweden \\ ${ }^{2}$ Department of Earth Sciences, Faculty of Geosciences, Utrecht University, Budapestlaan 4, \\ 3584 CD Utrecht, the Netherlands \\ ${ }^{3}$ University College London, Department of Chemistry, 20 Gordon Street, London, WC1H 0AJ, UK \\ Correspondence to: C. Lenz (conny.lenz@geol.lu.se)
}

Received: 11 April 2014 - Published in Biogeosciences Discuss.: 25 June 2014

Revised: 17 July 2015 - Accepted: 21 July 2015 - Published: 19 August 2015

\begin{abstract}
Expanding hypoxia in the Baltic Sea over the past century has led to the development of anoxic and sulfidic (euxinic) deep basins that are only periodically ventilated by inflows of oxygenated waters from the North Sea. In this study, we investigate the potential consequences of the expanding hypoxia for manganese (Mn) burial in the Baltic Sea using a combination of pore water and sediment analyses of dated sediment cores from eight locations. Diffusive fluxes of dissolved $\mathrm{Mn}$ from sediments to overlying waters at oxic, hypoxic and euxinic sites are consistent with an active release of $\mathrm{Mn}$ from these areas. Although the present-day fluxes are significant (ranging up to ca. $240 \mu \mathrm{mol} \mathrm{m}^{-2} \mathrm{~d}^{-1}$ ), comparison to published water column data suggests that the current benthic release of $\mathrm{Mn}$ is small when compared to the large pool of Mn already present in the hypoxic and anoxic water column. Our results highlight two modes of Mn carbonate formation in sediments of the deep basins. In the Gotland Deep area, Mn carbonates likely form from Mn oxides that are precipitated from the water column directly following North Sea inflows. In the Landsort Deep, in contrast, Mn carbonate and $\mathrm{Mn}$ sulfide layers appear to form independently of inflow events, and are possibly related to the much larger and continuous input of Mn oxides linked to sediment focusing. Whereas Mn-enriched sediments continue to accumulate in the Landsort Deep, this does not hold for the Gotland Deep area. Here, a recent increase in euxinia, as evident from measured bottom water sulfide concentrations and elevated sediment molybdenum (Mo), coincides with a decline in sediment Mn content. Sediment analyses also reveal that recent inflows of oxygenated water (since ca. 1995) are no longer
\end{abstract}

consistently recorded as Mn carbonate layers. Our data suggest that eutrophication has not only led to a recent rise in sulfate reduction rates but also to a decline in reactive $\mathrm{Fe}$ input to these basins. We hypothesize that these factors have jointly led to higher sulfide availability near the sedimentwater interface after inflow events. As a consequence, the $\mathrm{Mn}$ oxides may be reductively dissolved more rapidly than in the past and Mn carbonates may no longer form. Using a simple diagenetic model for Mn dynamics in the surface sediment, we demonstrate that an enhancement of the rate of reduction of Mn oxides is consistent with such a scenario. Our results have important implications for the use of Mn carbonate enrichments as a redox proxy in marine systems.

\section{Introduction}

Manganese (Mn) enrichments in brackish and marine sedimentary deposits can be used as an indicator of redox changes in the overlying waters (e.g. Calvert and Pedersen, 1993). In anoxic settings, Mn enrichments are typically assumed to consist of Mn carbonates, which are associated with calcium and can contain other impurities (e.g. Jakobsen and Postma, 1989; Manheim, 1961; Sternbeck and Sohlenius, 1997; Suess, 1979). For simplicity, in this study these phases are collectively referred to as Mn carbonates, despite their obvious greater complexity and heterogeneity. Mn carbonate minerals are suggested to form from Mn oxides deposited during periods of bottom water oxygenation (Calvert and Pedersen, 1996; Huckriede and Meischner, 1996), with 
dissolved Mn availability thought to be the key control (Neumann et al., 2002). Nevertheless, sediment Mn data for both the Landsort Deep in the Baltic Sea (Lepland and Stevens, 1998) and the Black Sea (Lyons and Severmann, 2006) indicate that Mn enrichments may also form in sediments overlain by continuously anoxic bottom waters. In the Landsort Deep, these enrichments consist of both Mn carbonates and Mn sulfides (Lepland and Stevens, 1998; Suess, 1979). The formation of Mn carbonate is assumed to be driven by an exceptionally high alkalinity derived from sulfate reduction, whereas Mn sulfides form when $\mathrm{H}_{2} \mathrm{~S}$ exceeds Fe availability (Böttcher and Huckriede, 1997; Lepland and Stevens, 1998). Some Mn may also be incorporated in pyrite (e.g. HuertaDiaz and Morse, 1992; Jacobs et al., 1985), but the amounts are relatively minor when compared to those present in $\mathrm{Mn}$ carbonate, as shown in a recent study on Baltic Sea sediments (Lenz et al., 2014). Finally, Mn enrichments may also form in sediments overlain by oxic bottom waters upon increased input and precipitation of Mn oxides and transformation to $\mathrm{Mn}$ carbonate during burial (e.g. Macdonald and Gobeil, 2012). A better understanding of the various modes of formation of sedimentary $\mathrm{Mn}$ and the link with variations in bottom water redox conditions is essential when interpreting Mn enrichments in geological deposits (e.g. Calvert and Pedersen, 1996; Huckriede and Meischner, 1996; Jones et al., 2011; Meister et al., 2009).

Redox-dependent dynamics of Mn have been studied extensively in the Baltic Sea (e.g. Huckriede and Meischner, 1996; Lepland and Stevens, 1998; Neumann et al., 2002) and are of interest because of the large spatial and temporal variations in bottom water oxygen conditions over the past century that have been particularly well documented since the 1970's (Fonselius and Valderrama, 2003). The available hydrographic data provide evidence for sporadic inflows of oxygenated saline water from the North Sea that affect brackish bottom waters in all deep basins (Matthäus and Franck, 1992; Matthäus et al. 2008). Since the end of the 1970's, the frequency of North Sea inflows has declined from multiple events per decade to only one inflow per decade (e.g. Mohrholz et al., 2015). Between inflows, when bottom waters in the deep basins of the Baltic Sea are anoxic, pore waters in the surface sediments are typically assumed to be undersaturated with respect to $\mathrm{Mn}$ carbonates down to a depth of $\sim 5$ to $8 \mathrm{~cm}$, based on saturation state calculations for idealized minerals (Carman and Rahm, 1997; Heiser et al., 2001). Mn oxides that formed during oxic inflows and settled in the surface sediment will dissolve upon subsequent exposure to reducing pore water or overlying water. This is thought to lead to high dissolved Mn concentrations in the pore water during - and shortly after - the inflow events. The high Mn concentrations may lead in turn to strong oversaturation with respect to Mn carbonates, although this has not been proven due to the lack of real-time studies during inflow events (Huckriede and Meischner, 1996; Sternbeck and Sohlenius, 1997; Heiser et al., 2001). Furthermore, high Mn concentrations must coincide with sufficiently high alkalinity for Mn carbonate precipitation to initiate (Lepland and Stevens, 1998). Despite these uncertainties, various authors have correlated historically-recorded inflow events to specific accumulations of $\mathrm{Mn}$ carbonate in sediments of the Gotland Basin (e.g. Heiser et al., 2001; Neumann et al., 1997).

Hydrographic data also indicate a major expansion of the hypoxic area in the Baltic Sea over the past century. This expansion is primarily caused by increased eutrophication, implying that the oxygen demand in deeper waters has increased as a result of higher organic matter supply (Carstensen et al., 2014; Conley et al., 2009; Gustafsson et al., 2012; Savchuk et al., 2008). While the shallower areas in the Baltic Sea are now seasonally hypoxic, the deep basins all show a major shift towards anoxic and sulfidic (euxinic) conditions around 1980 (Fonselius and Valderrama, 2003; Mort et al., 2010). These basin-wide changes in redox conditions likely had a major impact on both the sources and sinks of sediment Mn in the Baltic Sea.

River input (Ahl, 1977; Martin and Meybeck, 1979) and release from sediments (Sundby et al., 1981; Yeats et al., 1979) are the key sources of Mn in the water column of marine coastal basins. Whereas in areas with oxic bottom waters, dissolved Mn produced in the sediment will mostly be oxidized to Mn oxide in the surface layer and thus will be trapped in the sediment, dissolved Mn may escape to the overlying water when the oxic surface layer is very thin (Slomp et al., 1997). In the water column, this Mn may be oxidized again (e.g. Dellwig et al., 2010; Turnewitsch and Pohl, 2010) and contribute to the depositional flux of Mn oxides (Mouret et al., 2009), or may be laterally transferred in dissolved or particulate form. The lateral transfer of $\mathrm{Mn}$ from oxic shelves to deep basins, where the Mn may be trapped and ultimately may precipitate as authigenic minerals, is termed the "Mn shuttle" (Lyons and Severmann, 2006).

During the expansion of hypoxia and anoxia, as observed in the Baltic Sea over the past century (Conley et al., 2009), the Mn shuttle likely became more efficient in transporting Mn to deeper, euxinic basins because of decreased trapping of $\mathrm{Mn}$ in oxygenated surface sediments (Lyons and Severmann, 2006). However, during an extended period of hypoxia and anoxia, sediments in hypoxic areas may become depleted of Mn oxides, thus reducing the strength of the Mn shuttle from oxic and hypoxic shelves to the deep basins. In addition, the formation rate of authigenic Mn minerals in deep basin sediments may change in response to bottom water hypoxia and anoxia. If release of dissolved $\mathrm{Mn}^{2+}$ from $\mathrm{Mn}$ oxides - formed at the sediment surface following inflows of oxygenated North Sea water - is the dominant control for Mn carbonate formation in the sediment as suggested for the Gotland Deep (Neumann et al., 2002), expanding bottom water anoxia might allow Mn oxides to be reduced by sulfides in the anoxic and sulfidic water column and at the sediment-water interface, precluding conversion to Mn car- 
bonates. This mechanism was recently invoked to explain the lack of Mn carbonates in the sediment during periods of bottom water euxinia in the Gotland Deep during the Holocene Thermal Maximum (Lenz et al., 2014). A reduced shuttling of $\mathrm{Fe}$ oxides from shelves linked to expanding hypoxia (e.g. Lyons and Severmann, 2006) could contribute to this mechanism by reducing the buffering capacity of the sediments for sulfide (Diaz and Rosenberg, 2008). If alkalinity production is the key control, however, as suggested for the Landsort Deep (Lepland and Stevens, 1998), Mn sequestration would be expected to be similar or increase due to higher rates of sulfate reduction.

In this study, we use geochemical analyses of dated sediment cores for eight sites in the Baltic Sea, combined with pore water data to assess the role of variations in water column redox conditions for Mn dynamics in surface sediments in the Baltic Sea. We capture the full range of redox conditions (oxic, hypoxic and euxinic) to investigate the cycling of $\mathrm{Mn}$ in the sediment, the present-day diffusive flux from the sediments and the sequestration of Mn in mineral phases. Whereas the pore water data only provide a snapshot of the conditions at the time of sampling, the sediment data in the euxinic basins record both the expansion of hypoxia and anoxia and the effects of short-term inflows of oxygenated North Sea water. Our results indicate release of Mn from oxic and hypoxic areas as well as the deep basin sites, and sequestration of Mn carbonates and sulfides in the Landsort Deep. The lack of recent Mn accumulation at various deep basin sites suggests that inflows of oxygenated seawater are no longer consistently recorded by Mn carbonate deposits in these settings.

\section{Materials and methods}

\subsection{Study area}

Fine-grained, highly porous sediments from eight locations in the southern and central Baltic Sea were collected during four cruises between 2007 and 2011 (Fig. 1, Table 1) using a multi-corer. The sites differ with respect to their water depths and their present-day bottom water redox conditions. The Fladen and LF1 sites are located in the Kattegat and along the eastern side of the Gotland Deep, respectively, and are fully oxic, whereas site BY5 in the Bornholm Basin is seasonally hypoxic (Jilbert et al., 2011; Mort et al., 2010). The remaining stations, LF3, LL19, BY15 (Gotland Basin), F80 (Fårö Deep) and LD1 (Landsort Deep), are situated below the redoxcline, which was located between 80 and $120 \mathrm{~m}$ water depth at the time of sampling. Therefore, bottom waters at these sites were all anoxic and sulfidic (euxinic). The latter four sites are located in the deep central basins of the Baltic Sea, at water depths ranging from $169 \mathrm{~m}$ at LL19 to $416 \mathrm{~m}$ at LD1. When sampling the sediment at these sites, the weights of the multi-corer were reduced and the frame of the multi-corer was modified to prevent it from sinking into the soft sediment, allowing the retrieval of undisturbed sediment cores with overlying water. Water column data for oxygen and hydrogen sulfide for LL19 and LD1 (as recorded at LL23 as a nearby station) are available from the ICES Dataset on Ocean Hydrology (2014). The sampling as well as selected pore water and sediment analyses for many of our sites have been described previously (Mort et al., 2010; Jilbert et al., 2011; Jilbert and Slomp, 2013a). For completeness, all procedures are described below.

\subsection{Bottom water and pore water analyses}

A bottom water sample was taken from the water overlying the sediment in each multicore as soon as possible after core collection. At each site, sediment multicores $(<50 \mathrm{~cm}, 10 \mathrm{~cm}$ i.d.) were either immediately sectioned in a $\mathrm{N}_{2}$-filled glovebox at in situ temperature or sampled with syringes from which the top was cut off and that were pushed into the sediment through taped, pre-drilled holes in the core liner. The tape was cut with a sharp object directly prior to inserting the syringe. A small portion of each sample was stored at $5{ }^{\circ} \mathrm{C}$ or $-20^{\circ} \mathrm{C}$ in gas-tight jars for sediment analyses. The remaining sediment was centrifuged $(10-30 \mathrm{~min} ; 2500 \mathrm{~g})$ in $50 \mathrm{~mL}$ Greiner tubes to collect pore water. Both the pore water and a bottom water sample were filtered $(0.45 \mu \mathrm{m}$ pore size $)$ and subdivided for later laboratory analyses. All pore water handling prior to storage was performed in a $\mathrm{N}_{2}$ atmosphere. A subsample of $0.5 \mathrm{~mL}$ was directly transferred to a vial with $2 \mathrm{~mL}$ of a $2 \% \mathrm{Zn}$-acetate solution for analysis of hydrogen sulfide. Sulfide concentrations were determined by complexation of the $\mathrm{ZnS}$ precipitate using phenylenediamine and ferric chloride (Strickland and Parsons, 1972). The relative precision of the sulfide analyses determined for replicate samples was $<10 \%$. Subsamples for total Mn, Fe, Ca and S were acidified with either $\mathrm{HNO}_{3}$ (Fladen, BY5) or $\mathrm{HCl}$ (all other stations) and stored at $5{ }^{\circ} \mathrm{C}$ until further analysis by inductively coupled plasma optical emission spectroscopy (ICPOES; Perkin Elmer Optima 3000; relative precision and accuracy as established by standards (ISE-921) and duplicates were always $<5 \%$ ). Hydrogen sulfide was assumed to be released during the initial acidification, thus $\mathrm{S}$ is assumed to represent $\mathrm{SO}_{4}^{2-}$ only. Total $\mathrm{Mn}$ and $\mathrm{Fe}$ are assumed to represent $\mathrm{Mn}^{2+}$ and $\mathrm{Fe}^{2+}$ although in the former case, some $\mathrm{Mn}^{3+}$ may also be included (Madison et al., 2011). Subsamples for $\mathrm{NH}_{4}$ were frozen at $-20^{\circ} \mathrm{C}$ until spectrophotometric analysis using the phenol hypochlorite method (Riley, 1953). The relative precision of the $\mathrm{NH}_{4}^{+}$analyses was $<5 \%$. A final subsample was used to determine the $\mathrm{pH}$ with a $\mathrm{pH}$ electrode and meter (Sentron). We note that degassing of $\mathrm{CO}_{2}$ may impact ex situ $\mathrm{pH}$ measurements, leading to a rise in $\mathrm{pH}$ (Cai and Reimers, 1993). Hence, our reported $\mathrm{pH}$ values should be considered as approximate. The total alkalinity was then determined by titration with $0.01 \mathrm{M} \mathrm{HCl}$ with a precision of 

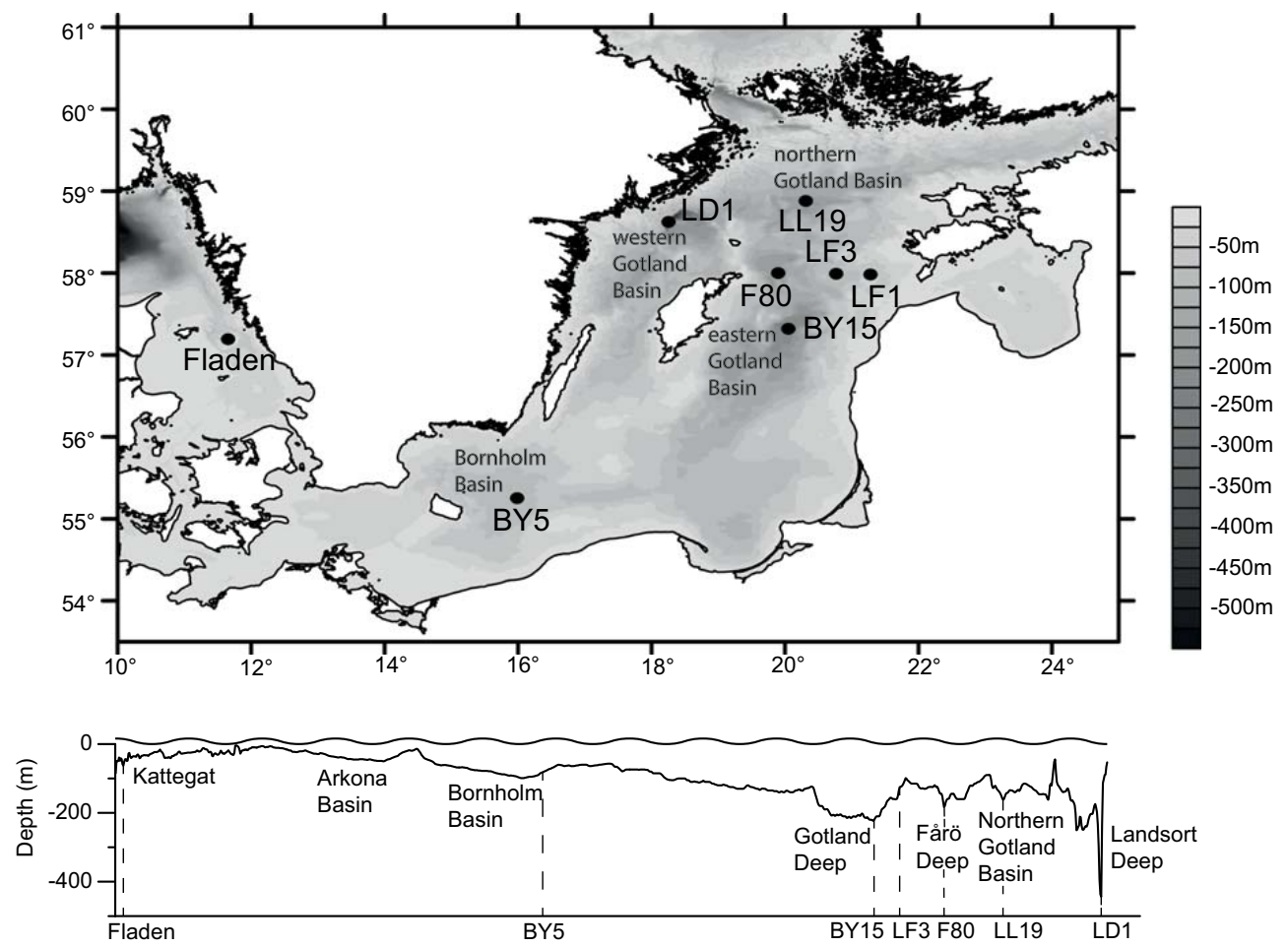

Figure 1. Bathymetric map and depth profile of the Baltic Sea showing the locations of the sampling sites.

$0.05 \mathrm{meq} / \mathrm{L}$. All colorimetric analyses were performed with a Shimadzu spectrophotometer.

At four deep basin sites (LL19, BY15, F80, LD1), a second multicore was sampled and analysed for methane as described by Jilbert and Slomp (2013a). Briefly, a cut-off syringe was inserted into a pre-drilled, taped hole at $1.5 \mathrm{~cm}$ intervals directly after core collection. Precisely $10 \mathrm{~mL}$ wet sediment was extracted from each hole and transferred immediately to a $65 \mathrm{~mL}$ glass bottle filled with a saturated sodium chloride $(\mathrm{NaCl})$ solution. This bottle was then closed with a rubber stopper and screw cap, and a headspace of $10 \mathrm{~mL} \mathrm{~N}_{2}$ gas was inserted. The bottles were shaken and then stored upside down at room temperature for ca. 1 month before analysis in the laboratory at Utrecht. Selected samples were analysed again after 1 year and gave identical results. Methane was assumed to be quantitatively salted out into the headspace during the equilibration process. As determined by O'Sullivan and Smith (1970), methane is effectively insoluble in a $\mathrm{NaCl}$ solution of molality 4 at 100 atmosphere pressure and $51{ }^{\circ} \mathrm{C}$. In our case, the molality of the saturated salt solution was $\sim 5$, pressure was 1 atmosphere and temperature was $25^{\circ} \mathrm{C}$. As shown by the same authors, methane solubility declines with increasing salinity and decreasing pressure and is effectively independent of temperature, so our assumption of insolubility is valid. A similar method has been employed successfully by e.g. Mastalerz et al. (2009). Methane concentrations in the headspace of the glass bottles were determined by injection of a subsample into a Thermo Finnigan Trace GC gas chromatograph (flame ionization detector, Restek Q-PLOT column of $30 \mathrm{~m}$ length, $0.32 \mathrm{~mm}$ internal diameter, oven temperature $25^{\circ} \mathrm{C}$ ). Data were then back-calculated to the original pore water concentrations using the measured porosities (see Sect. 2.3). Because of degassing, which is unavoidable at sites with very high $\mathrm{CH}_{4}$ concentrations, the $\mathrm{CH}_{4}$ profile at $\mathrm{LD} 1$ is expected to have a larger error than at other sites, and likely represents a minimum estimate of the true concentrations.

\subsection{Sediment analyses}

Sediment samples were freeze-dried and water contents and porosities were calculated from the weight loss, assuming a sediment density of $2.65 \mathrm{~g} \mathrm{~cm}^{-3}$. Sediments were then ground in an agate mortar in a $\mathrm{N}_{2}$ or argon-filled glovebox. From each sediment sample, aliquots for several different analyses were taken. For total organic carbon (TOC) analyses, $0.3 \mathrm{~g}$ of sediment was decalcified with $1 \mathrm{M} \mathrm{HCl}$ and the $\mathrm{C}$ content was determined with a Fisons NA 1500 CNS analyser (van Santvoort et al., 2002), whereafter the measured TOC content in the decalcified sediment was converted to the content in the original sediment using the weight loss during decalcification. Based on the analyses of laboratory reference materials and replicates, the relative error of the TOC measurements was generally less than $5 \%$. Total sediment contents of $\mathrm{S}, \mathrm{Mn}, \mathrm{Ca}, \mathrm{Fe}, \mathrm{Al}$ and Mo were determined by ICP-OES, after dissolution of $0.125 \mathrm{~g}$ of sample with 
Table 1. Characteristics of the eight study sites in the Baltic Sea. Redox: bottom water redox conditions at the time of sampling. Pore water samples were obtained during every cruise and were similar between years at each station. Here, the most complete data sets for each station are presented. Average sedimentation rates for the last 30 years are based on ${ }^{210} \mathrm{~Pb}$ dating.

\begin{tabular}{|c|c|c|c|c|c|c|c|}
\hline Site name & Location & Cruise & Position & $\begin{array}{r}\text { Water } \\
\text { depth } \\
(\mathrm{m})\end{array}$ & $\begin{array}{r}\text { Sedimentation } \\
\text { rate } \\
\left(\mathrm{cm} \mathrm{yr}^{-1}\right)\end{array}$ & Redox & Salinity \\
\hline Fladen & Fladen & $\begin{array}{l}\text { R/V Skagerak } \\
\text { Sept. } 2007\end{array}$ & $\begin{array}{l}57^{\circ} 11.57 \mathrm{~N} \\
11^{\circ} 39.25 \mathrm{E}\end{array}$ & 82 & 1.0 & oxic & 34.2 \\
\hline LF1 & $\begin{array}{l}\text { Northern } \\
\text { Gotland Basin }\end{array}$ & $\begin{array}{l}\text { R/V Aranda } \\
\text { May/June } 2009\end{array}$ & $\begin{array}{l}57^{\circ} 58.95 \mathrm{~N} \\
21^{\circ} 16.84 \mathrm{E}\end{array}$ & 67 & 0.25 & oxic & 8.2 \\
\hline BY5 & $\begin{array}{l}\text { Bornholm } \\
\text { Basin }\end{array}$ & $\begin{array}{l}\text { R/V Skagerak } \\
\text { Sept. } 2007\end{array}$ & $\begin{array}{l}55^{\circ} 15.16 \mathrm{~N} \\
15^{\circ} 59.16 \mathrm{E}\end{array}$ & 89 & 0.23 & $\mathrm{O}_{2}=4.0 \mu \mathrm{M}$ & 16.2 \\
\hline LF3 & $\begin{array}{l}\text { Eastern } \\
\text { Gotland Basin }\end{array}$ & $\begin{array}{l}\text { Sediment: } \\
\text { R/V Aranda } \\
\text { May/June } \\
2009 \\
\text { Pore water: } \\
\text { R/V Pelagia } \\
\text { May 2011 }\end{array}$ & $\begin{array}{l}57^{\circ} 59.50 \mathrm{~N} \\
20^{\circ} 46.00 \mathrm{E}\end{array}$ & 95 & 0.50 & $\mathrm{H}_{2} \mathrm{~S}=2.9 \mu \mathrm{M}$ & 10.1 \\
\hline LL19 & $\begin{array}{l}\text { Northern } \\
\text { Gotland Basin }\end{array}$ & $\begin{array}{l}\text { Sediment: } \\
\text { R/V Aranda } \\
\text { May/June } \\
2009 \\
\text { Pore water: } \\
\text { R/V Heincke } \\
\text { July } 2010\end{array}$ & $\begin{array}{l}58^{\circ} 52.84 \mathrm{~N} \\
20^{\circ} 18.65 \mathrm{E}\end{array}$ & 169 & 0.30 & $\mathrm{H}_{2} \mathrm{~S}=19.9 \mu \mathrm{M}$ & 11.4 \\
\hline BY15 & Gotland Deep & $\begin{array}{l}\text { Sediment } \\
\text { R/V Aranda } \\
\text { May/June } \\
2009 \\
\text { Pore water: } \\
\text { R/V Heincke } \\
\text { July } 2010\end{array}$ & $\begin{array}{l}57^{\circ} 19.20 \mathrm{~N} \\
20^{\circ} 03.00 \mathrm{E}\end{array}$ & 238 & 0.27 & $\mathrm{H}_{2} \mathrm{~S}=74.1 \mu \mathrm{M}$ & 12.5 \\
\hline F80 & Fårö Deep & $\begin{array}{l}\text { Sediment: } \\
\text { R/V Aranda } \\
\text { May/June } \\
2009 \\
\text { Pore water: } \\
\text { R/V Heincke } \\
\text { July } 2010\end{array}$ & $\begin{array}{l}58^{\circ} 00.00 \mathrm{~N} \\
19^{\circ} 53.81 \mathrm{E}\end{array}$ & 191 & 0.55 & $\mathrm{H}_{2} \mathrm{~S}=45.6 \mu \mathrm{M}$ & 12.0 \\
\hline LD1 & Landsort Deep & $\begin{array}{l}\text { R/V Pelagia } \\
\text { May } 2011\end{array}$ & $\begin{array}{l}58^{\circ} 37.47 \mathrm{~N} \\
18^{\circ} 15.23 \mathrm{E}\end{array}$ & 416 & 0.77 & anoxic and sulfidic & 10.6 \\
\hline
\end{tabular}

an $\mathrm{HF} / \mathrm{HClO}_{4} / \mathrm{HNO}_{3}$ mixture in closed Teflon bombs at $90^{\circ} \mathrm{C}$, followed by evaporation of the solution and redissolution of the remaining gel in $1 \mathrm{M} \mathrm{HNO}_{3}$ (Passier et al., 1999). The accuracy and precision of the measurements were established by measuring laboratory reference materials (ISE-921 and in-house standards) and sample replicates; relative errors were $<5 \%$ for all reported elements. The detection limits of ICP-OES for $\mathrm{Mn}, \mathrm{Mo}, \mathrm{Ca}, \mathrm{Fe}, \mathrm{Al}$ and $\mathrm{S}$ in the $\mathrm{HNO}_{3}$ solution are $0.6,14,5,6$ and $24 \mu \mathrm{g} \mathrm{kg}^{-1}$ and $0.28 \mathrm{mg} \mathrm{kg}^{-1}$, respectively. All elemental concentrations in the sediment were 
corrected for the weight of the salt in the pore water using the ambient salinity and porosity.

Age models based on ${ }^{210} \mathrm{~Pb}$ analyses for six multicores used in this study have been previously published. For details, we refer the reader to the relevant studies: Fladen and BY5 (Mort et al., 2010), LF1 and LF3 (Jilbert et al., 2011), LL19 (Zillén et al., 2012) and BY15 (Jilbert and Slomp, 2013b). A new ${ }^{210} \mathrm{~Pb}$ age model was constructed for LD1. Samples from the Landsort Deep (LD1) were analysed with a Canberra BeGe gamma-ray spectrometer at Utrecht University. The samples were freeze-dried, homogenized, and transferred into vent-free petri dishes, which were sealed in polyethylene bags and stored for 2 weeks before the measurement was taken. Each sample was measured until 200$250{ }^{210} \mathrm{~Pb}$ gamma-ray counts were reached. For the age determination, a constant rate of supply model (Appleby and Oldfield, 1983) was implemented using a background estimated from the mean counts of ${ }^{214} \mathrm{~Pb}$ and ${ }^{214} \mathrm{Bi}$. For further details on the age models and the ${ }^{210} \mathrm{~Pb}$ data for $\mathrm{LD} 1$, we refer to Supplement 1.

The age model for the site in the Fårö Deep (F80) was constructed using high-resolution Mo and Mn data. In 2013, an extra sediment core was taken from this station. Mini sub-cores of the upper sediments were embedded in Spurr's epoxy resin and measured by laser ablation-inductively coupled plasma mass spectrometry (LA-ICP-MS) line scanning (see Sect. 2.4). Due to non-linear compaction of the sediments during the embedding procedure, the depth scale of the LA-ICP-MS data was adjusted by alignment to discrete sample data from the corresponding core section (not shown). Subsequently, fluctuations in $\mathrm{Mo} / \mathrm{Al}$ and $\mathrm{Mn} / \mathrm{Al}$ ratios were compared with instrumental records of bottom water oxygen conditions, and ages were assigned to features in the $\mathrm{Mo} \mathrm{/} \mathrm{Al}$ and $\mathrm{Mn} / \mathrm{Al}$ profiles (Supplement 1; Fig. S2). The adjustment of the depth scale and the allocation of ages allowed sedimentation rates to be estimated (Supplement 1; Fig. S3). The 2009 multicore profiles from F80 were then tuned to the dated profiles from 2013 (see Supplement 1 for more details).

\subsection{Microanalysis}

Mini sub-cores of $1 \mathrm{~cm}$ diameter and up to $\sim 12 \mathrm{~cm}$ length each were taken from the top part of sediment multicores at sites LL19 and LD1 in May 2011 as described in detail by Jilbert and Slomp (2013b). Briefly, the pore water was replaced by acetone and the sub-core was fixed in Spurr's epoxy resin. During the whole procedure the sub-cores remained upright. During the dewatering process the sediment compacted resulting in a reduction of length of both sections by up to $50 \%$. After curing, epoxy-embedded sub-cores were opened perpendicular to the plane of sedimentation and the exposed internal surface was polished.

Line scans were performed with LA-ICP-MS, to measure high-resolution vertical profiles of selected elements in the resin blocks of the two cores (Hennekam et al., 2015). A Lambda Physik laser with a wavelength of $193 \mathrm{~nm}$ and pulse rate of $10 \mathrm{~Hz}$ was focused onto the sample surface with a spot size of $120 \mu \mathrm{m}$. During line scanning, the sample was moved under the laser beam at $0.0275 \mathrm{~mm} / \mathrm{s}$, creating an overlapping series of pulse craters. From the closed sample chamber, the ablated sample was transferred to a Micromass Platform ICP-MS by He-Ar carrier gas. Specific isotopes of aluminum $\left({ }^{27} \mathrm{Al}\right)$, iron $\left({ }^{57} \mathrm{Fe}\right)$, manganese $\left({ }^{55} \mathrm{Mn}\right)$, sulfur $\left({ }^{34} \mathrm{~S}\right)$ and molybdenum $\left({ }^{98} \mathrm{Mo}\right)$ were measured. For site LD1, bromine $\left({ }^{81} \mathrm{Br}\right)$ was also measured. LA-ICP-MS data for each element were calibrated by reference to the sensitivities (counts/ppm) of the glass standard NIST SRM 610 (Jochum et al., 2011) and corrected for the natural abundances of the analysed isotopes. All data are reported normalized to $\mathrm{Al}$ to correct for variations in sample yield. For S / Al data, a further sensitivity factor was applied which compensates for the contrasting relative yield of S from NIST SRM 610 with respect to embedded sediments.

The resin-embedded samples were also mounted inside an EDAX Orbis Micro-XRF Analyzer to construct elemental maps at a spatial resolution of $30 \mu \mathrm{m}$ for manganese $(\mathrm{Mn})$, calcium $(\mathrm{Ca})$ and sulfur (S) (Micro-XRF settings: Rh tube at $30 \mathrm{kV}, 500 \mu \mathrm{A}, 300 \mathrm{~ms}$ dwell time, $30 \mu \mathrm{m}$ capillary beam).

\subsection{Flux calculations}

The diffusive flux of manganese across the sediment-water interface $\left(J_{\text {sed }}\right)$ was calculated from the concentration gradient that was obtained from the difference in concentration in the bottom water and the first pore water sample (with the depths of this first sample ranging from 0.25 to $2.5 \mathrm{~cm}$ ) using Fick's first law for six sites, assuming that most dissolved $\mathrm{Mn}$ is in the form of $\mathrm{Mn}^{2+}$ :

$J_{\text {sed }}=-\phi D_{\text {sed }} \frac{\mathrm{d} C_{\mathrm{Mn} 2+}}{\mathrm{d} x}$,

where $\varphi$ is the porosity (as listed in Supplement 2), $D_{\text {sed }}$ is the whole sediment diffusion coefficient for dissolved $\mathrm{Mn}^{2+}$, $C$ is the dissolved $\mathrm{Mn}^{2+}$ concentration and $\mathrm{x}$ is depth in the sediment. $D_{\text {sed }}$ was calculated from the diffusion coefficient of $\mathrm{Mn}^{2+}$ in free solution corrected for ambient salinity and temperature $\left(D_{\mathrm{SW}}\right)$ and porosity (Boudreau, 1997):

$D_{\text {sed }}=\frac{D_{\mathrm{SW}}}{\left(1-\ln \phi^{2}\right)}$.

Whenever possible (LL19, BY15 and F80), higher resolution data from the 2009 Aranda cruise were used for the calculation (Table 2 and data in Supplement 2).

\subsection{Saturation state}

Thermodynamic equilibrium calculations were performed for the pore water of LF3, LL19, BY15, F80 and LD1 using version 3.1.1 of the computer program PHREEQC 
Table 2. Diffusive fluxes of Mn across the sediment-water interface at all six sites. For further details, see text. For the bottom water and pore water data, see Supplement 2.

\begin{tabular}{lllll}
\hline Site & Location & Year and cruise & $\begin{array}{l}\text { Depth } \\
\text { range } \\
\mathrm{cm}\end{array}$ & $\begin{array}{l}\text { Diffusive } \\
\text { Mn flux } \\
\mu \mathrm{mol} \mathrm{m}^{-2} \mathrm{~d}^{-1}\end{array}$ \\
\hline LF1 & $\begin{array}{l}\text { Northern } \\
\text { Gotland Basin }\end{array}$ & 2009 R/V Aranda & BW-0.25 & 115 \\
\hline BY5 & $\begin{array}{l}\text { Bornholm } \\
\text { Basin }\end{array}$ & 2009 R/V Aranda & BW-0.5 & 236 \\
\hline LL19 & $\begin{array}{l}\text { Northern } \\
\text { Gotland Basin }\end{array}$ & 2009 R/V Aranda & BW-0.25 & 81 \\
\hline BY15 & Gotland Deep & 2009 R/V Aranda & BW-0.25 & 98 \\
\hline F80 & Fårö Deep & 2009 R/V Aranda & BW-0.25 & 84 \\
\hline LD1 & Landsort Deep & 2011 R/V Pelagia & BW*-2.5 & $\sim 220$ \\
\hline * LD1 has no measured bottom water sample. Therefore, the flux was estimated using the bottom water \\
value from the Landsort Deep site BY31 from Mort et al. 2010.
\end{tabular}

(Parkhurst and Appelo, 1999) with the LLNL database. Our calculations should be seen as approximations with the main purpose of providing a comparison to previous calculations by Carman and Rahm (1997) and Heiser et al. (2001) to assess whether there are any indications for a change in saturation state of the pore water between inflows. The LLNL database does not contain the authigenic carbonate phases present in the Baltic Sea. Data from the literature (Jakobsen and Postma, 1989; Sternbeck and Sohlenius, 1997; Lepland and Stevens, 1998; Huckriede and Meischner 1996; Kulik et al., 2000) suggest that Baltic carbonates are predominantly Mn carbonates with a substantial contribution of $\mathrm{Ca}$. Therefore, an approximation of the solubility product of (Mn, Ca) $\mathrm{CO}_{3}$ solid solutions was generated using the equations given in Katsikopoulos et al. (2009). The stoichiometric solubility product $\left(K_{\text {st }}\right)$ was calculated using $\mathrm{Mn}_{0.74} \mathrm{Ca}_{0.26} \mathrm{CO}_{3}$ (Kulik et al., 2000) as a common ratio measured for (Mn, $\mathrm{Ca}) \mathrm{CO}_{3}$ solid solutions in Baltic Sea sediments.

An equilibrium constant pK of 0.377 (Emerson et al., 1983) was used for Mn sulfide. The solubility of iron sulfide from Rickard (2006) was added to the database as well as $\mathrm{MnHS}^{+}$as a solute (Luther et al., 1996) because it is likely abundant in pore water in sulfidic sediments (Heiser et al., 2001). At sites LF3 and LD1, $\mathrm{Fe}^{2+}$ was below the detection limit and the calculation of the saturation state with respect to FeS could not be performed. Carbonate alkalinity was calculated from titration alkalinity as described by Carman and Rahm (1997).

\subsection{Diagenetic model for Mn}

A simple diagenetic model for Mn was developed to assess the potential effect of changes in the kinetics of reductive dissolution of Mn oxides to dissolved $\mathrm{Mn}^{2+}$ and subsequent $\mathrm{Mn}$ carbonate formation in Baltic Sea surface sediments following an inflow event. Our modelling is generic and addresses this research question only. Therefore, we do not attempt to describe all the relevant processes potentially controlling $\mathrm{Mn}$ carbonate formation in the sediment nor do we focus on a specific location. The model accounts for two biogeochemical processes: reductive dissolution of $\mathrm{Mn}$ oxides to $\mathrm{Mn}^{2+}$ and precipitation of $\mathrm{Mn}^{2+}$ in the form of Mn carbonates. Empirical rate laws for $\mathrm{Mn}$ oxide reduction and $\mathrm{Mn}$ carbonate formation are assumed, with rates depending on first-order rate constants for both processes $\left(k_{\text {red }}\right.$ and $\left.k_{\text {prec }}\right)$ and the sediment concentration of $\mathrm{Mn}$ oxide and dissolved $\mathrm{Mn}^{2+}$, respectively (Berner, 1980; Slomp et al., 1997). The use of a first-order rate constant for a process that is more complex, does not imply that all other factors are ignored. Instead, it implies that all other factors are combined in the first-order rate constant (Berner, 1980). Here, the dependence of the rate of Mn carbonate formation on only dissolved Mn implies that we assume that alkalinity is never limiting for Mn carbonate formation. Transport is assumed to occur through diffusion $\left(\mathrm{Mn}^{2+}\right)$ and sediment burial $\left(\mathrm{Mn}^{2+}\right.$ and both solids). Porosity $(\varphi)$, temperature, sediment density $\left(\rho_{\mathrm{s}}\right)$ and rates of sedimentation $(\omega)$ are assumed constant with depth and time. The following differential equations were used: 


\section{Results}

$$
\begin{aligned}
& \frac{\partial C_{\mathrm{Mn}^{2+}}}{\partial t}=D_{\mathrm{Mn}^{2+}} \frac{\partial^{2} C_{\mathrm{Mn}^{2+}}}{\partial x^{2}}-\omega \frac{\partial C_{\mathrm{Mn}^{2+}}}{\partial x}-k_{\mathrm{prec}} C_{\mathrm{Mn}^{2+}} \\
& +\frac{\rho_{\mathrm{s}}(1-\phi)}{\phi} k_{\mathrm{red}} C_{\mathrm{Mn}_{\text {oxide }}} \\
& \frac{\partial C_{\mathrm{Mn}_{\text {oxide }}}}{\partial t}=-\omega \frac{\partial C_{\mathrm{Mn}_{\text {oxide }}}}{\partial x}-k_{\mathrm{red}} C_{\mathrm{Mn}_{\text {oxide }}} \\
& \frac{\partial C_{\mathrm{Mn}_{\mathrm{CO}_{3}}}}{\partial t}=-\omega \frac{\partial C_{\mathrm{Mn}_{\mathrm{CO}_{3}}}}{\partial x}+\frac{\phi}{\rho_{\mathrm{s}}(1-\phi)} k_{\mathrm{prec}} C_{\mathrm{Mn}^{2+}},
\end{aligned}
$$

where $C_{\mathrm{Mn}^{2+}}, C_{\mathrm{Mn}_{\text {oxide }}}$ and $C_{\mathrm{Mn}_{\mathrm{CO}_{3}}}$ are the concentrations of dissolved $\mathrm{Mn}^{2+}$, Mn oxides and $\mathrm{MnCO}_{3}$, respectively and $D_{\mathrm{Mn}^{2+}}$ is the diffusion coefficient of dissolved $\mathrm{Mn}^{2+}$ as defined in Eq. (2). The model code was written in R using the marelac (Soetaert et al., 2010) and ReacTran (Soetaert and Meysman, 2012) packages. The model domain is represented by a one-dimensional grid of 1000 cells that captures the interval from the sediment-water interface to a depth of $1 \mathrm{~cm}$. Environmental parameters typical for surface sediments in the deep basins of the Baltic Sea and boundary conditions were assumed as defined in Table 3.

Here, we assess a scenario for Baltic Sea sediments where Mn oxides are deposited during a period of oxic bottom water conditions for 4 months directly after a North Sea inflow followed by a period of 2 months in which no Mn oxides are deposited because of the return of bottom water anoxia (Table 3; Sect. 4.1). We assume that there is no $\mathrm{Mn}$ in the sediment (in any form) at the start of the scenario, consistent with Mn being low or absent in surface sediments in the Gotland Basin between inflows (Fig. 4). We set $k_{\text {prec }}$ to $5000 \mathrm{yr}^{-1}$, placing the maximum rate of $\mathrm{Mn}$ carbonate formation in the model calculations in the upper range given by Wang and Van Cappellen (1996). We then assess the response of benthic fluxes of $\mathrm{Mn}^{2+}$, rates of formation of Mn carbonate in the sediment and profiles of the various $\mathrm{Mn}$ forms to variations in $k_{\text {red }}$ when assuming values of either $0.1,1,10,100$ or $1000 \mathrm{yr}^{-1}$ during 4 months of the simulation followed by a period of 2 months with a $k_{\mathrm{red}}$ of $1000 \mathrm{yr}^{-1}$ (i.e. representing rapid $\mathrm{Mn}$ oxide reduction after the return of anoxic conditions). By varying $k_{\text {red }}$, we wish to capture a wide range in the availability of reductants for Mn oxides in the surface sediment. Values of $k_{\text {red }}$ estimated for different sedimentary environments overlain by oxic bottom waters in the North Sea range from 0.04 to $150 \mathrm{yr}^{-1}$ (Slomp et al., 1997). The slightly wider range assumed here is reasonable because of the more important role of anaerobic pathways of organic matter degradation in deep basin sediments of the Baltic Sea compared to those in the North Sea (e.g. Mort et al., 2010 vs. Slomp et al., 1997). To assess the robustness of our results, we also perform the same simulations with even higher $k_{\text {prec }}$ values (up to $30000 \mathrm{yr}^{-1}$ ).
At the time of sampling, bottom waters were oxic at the Fladen and LF1 sites in the eastern Gotland Basin, hypoxic at the Bornholm Basin site BY5, and anoxic and sulfidic at all other locations (Table 1). Pore water Mn concentrations increase with depth in the sediment at most sites (Fig. 2; Supplement 2). At the Fladen site, however, pore water Mn concentrations decrease again below ca. $5 \mathrm{~cm}$ and at the eastern Gotland Basin sites LF1 and LF3, Mn concentrations are lower than at other sites. Pore water Fe shows a subsurface maximum at the Fladen and LF1 sites, but is low or absent at all other sites. Pore water $\mathrm{Ca}^{2+}$ concentrations show little change with depth and are consistent with the salinity gradient in the Baltic Sea. Alkalinity and ammonium concentrations increase with sediment depth simultaneously with a decline in sulfate. $\mathrm{CH}_{4}$ is present at depth where sulfate is depleted at the sites in the Fårö Deep (F80) and Landsort Deep (LD1) (Supplement 2). Similar to $\mathrm{Ca}^{2+}$, sulfate concentrations in the bottom water at the different stations are consistent with the salinity gradient in the Baltic Sea (Table 1). Concentrations of hydrogen sulfide in the pore water $>2 \mathrm{mM}$ are found at the Fårö Deep and Landsort Deep sites F80 and LD1. The pore waters are supersaturated with respect to Mn carbonate below the surface sediment at the Landsort Deep. With the exception of LF3, the other hypoxic and anoxic sites reach saturation only at greater depth. For Mn sulfide, in contrast, supersaturation is only observed at the Landsort Deep site, LD1 (Fig. 3) and below $35 \mathrm{~cm}$ at site F80. Pore waters were supersaturated with respect to $\mathrm{FeS}$ at the sites in the northern Gotland Basin (LL19), in the Gotland Deep (BY15) and Fårö Deep (F80) (Supllement 2). We note that degassing of $\mathrm{CO}_{2}$ during centrifugation may have led to a shift in $\mathrm{pH}$ to higher values, thereby enhancing the degree of saturation with respect to carbonate and sulfide minerals. Nevertheless, an upward shift of ca. $0.5 \mathrm{pH}$ units due to this effect would not greatly affect the observed trends with depth and contrasts between stations in the calculated saturation states presented. Calculated diffusive fluxes of dissolved Mn vary from 81 to $236 \mu \mathrm{mol} \mathrm{m}^{-2} \mathrm{~d}^{-1}$, with the highest efflux from the sediment being observed at the hypoxic Bornholm Basin site BY5 and in the anoxic Landsort Deep (LD1) (Table 2).

Average sedimentation rates vary significantly between sites, with 3- to 4-fold higher rates at Fladen and in the Landsort Deep (LD1) when compared to the oxic site in the eastern Gotland Basin (LF1) and Bornholm Basin (BY5) (Table 1; Fig. 4). Sediments are highly porous, with porosities in the surface sediment ranging from 87 to 99 vol \% (Supplement 2) and rich in organic carbon (TOC) with maxima of ca. $5 \mathrm{wt} \%$ at the oxic sites Fladen and LF1 and ca. $16 \mathrm{wt} \%$ at the anoxic sites (Fig. 4). Whereas changes in TOC with depth at Fladen and LF1 are relatively small, distinct enrichments in TOC are observed in the upper part of the sediment at all anoxic sites. High contents of total Al, which is a proxy for 
Table 3. Environmental parameters, boundary conditions (where $x=0$ refers to the sediment-water interface and $x=1 \mathrm{~cm}$ refers to a depth of $1 \mathrm{~cm}$ in the sediment) and first-order rate constants used in the simple diagenetic model for Mn for a "typical" Gotland Basin sediment, including the sources, where relevant.

\begin{tabular}{|c|c|c|}
\hline $\begin{array}{l}\text { Environmental and transport parame- } \\
\text { ters }\end{array}$ & Value & Source \\
\hline $\begin{array}{l}\text { - Porosity }(\mathrm{vol} \%) \\
\text { - Temperature }\left({ }^{\circ} \mathrm{C}\right) \\
\text { - Salinity } \\
\text { - Sedimentation rate }\left(\mathrm{m} \mathrm{yr}^{-1}\right)\end{array}$ & $\begin{array}{l}99 \\
5 \\
12 \\
0.0025\end{array}$ & $\begin{array}{l}\text { Supplement } 2 \\
\text { Supplement } 2 \\
\text { Table } 1 \\
\text { Table } 1\end{array}$ \\
\hline $\begin{array}{l}\text { Boundary condition at sediment water } \\
\text { interface }(x=0)^{*} \\
\text { Fixed concentration, } \mathrm{Mn}^{2+}\left(\mathrm{mol} \mathrm{m}^{-3}\right) \\
\text { Fixed flux of } \mathrm{MnCO}_{3}\left(\mathrm{~mol} \mathrm{~m}-2 \mathrm{yr}^{-1}\right) \\
\text { Transient flux of } \mathrm{Mn} \text { oxides } \\
\left(\mathrm{mol} \mathrm{m}-2 \mathrm{yr}^{-1}\right)\end{array}$ & $\begin{array}{l}0 \\
0 \\
4 \text { months: } 1 \text {, then } 0\end{array}$ & $\begin{array}{l}\text { Typical for oxic waters } \\
\text { Assuming all formation in the sediment } \\
\text { Sect. } 4.1,0.33 \mathrm{~mol} \mathrm{~m}^{-2} \text { deposited } \\
\text { in } 4 \text { months }\end{array}$ \\
\hline $\begin{array}{l}\text { Rate constants } \\
-k_{\text {red }}\left(\mathrm{yr}^{-1}\right) \\
-k_{\text {prec }}\left(\mathrm{yr}^{-1}\right)\end{array}$ & $\begin{array}{l}\text { Range of } 0.1 \text { to } 1000 \\
5000\end{array}$ & $\begin{array}{l}\text { Slomp et al. (1997), Wang and } \\
\text { Van Cappellen (1996); see text } \\
\text { Wang and Van Cappellen (1996); } \\
\text { see text }\end{array}$ \\
\hline
\end{tabular}

* For all chemical species a zero-gradient boundary condition was specified at the bottom of the model domain.

clays, are consistent with the presence of fine-grained sediments throughout the cores (Supplement 2). Total sulfur contents are low at Fladen, but are higher at all other sites, and show considerable variation with depth in the sediment. Mn is enriched in the surface sediment at Fladen, but is nearly absent at the LF1, BY5 and LF3 sites. At sites LL19, BY15 and F80, Mn is present but mostly observed at greater depth in the sediment. The upper $30 \mathrm{~cm}$ of the sediment at site LD1 is highly enriched in Mn. Sediment $\mathrm{Ca}$ is high at Fladen, is enriched in the surface sediment at site LF1, is low at sites BY5, LF3 and LL19 and follows the pattern in Mn at sites BY15, F80 and LD1. Sediment Fe typically ranges from 2 to $6 \mathrm{wt} \%$ and there is a trend towards lower Fe contents in the upper 5 to $20 \mathrm{~cm}$ of the sediment, following an initial maximum at the bottom of the TOC-rich interval at many sites (Supplement 2). This upward declining trend is even more apparent when the Fe contents are normalized to Al (Fig. 4). Sediment Mo is low at the Fladen, LF1, BY5 and LF3 sites but is enriched at the other sites, where profiles largely follow those of TOC (Fig. 4).

The LA-ICP-MS line scans of resin-embedded surface sediments at site LL19 in the northern Gotland Basin (Fig. 5a) support the results of the discrete sample analysis (Fig. 4) and confirm that there are very few Mn-rich laminae in recent sediments at this location. Whereas most of the minor enrichments of $\mathrm{Mn}$ are correlated with $\mathrm{Fe}, \mathrm{S}$ and Mo (Fig. 5a), three peaks (at 3.6, 3.9 and $4.6 \mathrm{~cm}$ ) are independent of these elements, suggesting that these Mn enrichments dominantly consist of carbonates. This is confirmed by the Micro-XRF maps (Fig. 5b) of the corresponding in- terval, which indicate coincident $\mathrm{Mn}$ and Ca-rich layers. The maps show clear Mn carbonate layers at $\sim 3.9$ and $\sim 4.6 \mathrm{~cm}$. A third enrichment at $3.6 \mathrm{~cm}$ is less continuous and is only represented by one spot on the map. The two distinct Mn carbonate layers can be linked to inflow events in 1993 and 1997 , using the ${ }^{210} \mathrm{~Pb}$-based age model for this site, after correction for compaction of the sediment during embedding.

In the surface sediments of the Landsort Deep site (LD1), in contrast, a large number of Mn enrichments with much higher concentrations than at LL19 are observed (Figs. 4 and 5). The LA-ICP-MS line scans show that the highest values often coincide with enrichments in S, Mo and Br but are not related to maxima in $\mathrm{Fe}$. The micro-XRF maps of $\mathrm{Mn}, \mathrm{Ca}$ and $\mathrm{S}$ confirm that enrichments in $\mathrm{Mn}$ are present as discrete layers. The RGB (red, green, blue; $\mathrm{Mn}, \mathrm{Ca}, \mathrm{S}$, respectively) composite reveals two different compositions for the Mn enrichments. The purple layers in the RGB composite are a result of enrichments of $\mathrm{Mn}$ (red) and $\mathrm{S}$ (blue) in the same pixel, suggesting the presence of $\mathrm{Mn}$ sulfide. Other layers and spots are orange to yellow, indicating coincident enrichments of Ca (green) and Mn, suggesting carbonate enrichments (Fig. 5b).

The change in the integrated amount of Mn oxide and Mn carbonate in the sediment with time, as calculated using the diagenetic model, depends on the value of the rate constant for the reduction of $\mathrm{Mn}$ oxides $\left(k_{\mathrm{red}}\right)$ assumed for the period with oxic (4 months) bottom waters (Fig. 6a and b). The amount of Mn oxide that is preserved during this phase decreases with increasing values of $k_{\text {red. }}$. When $k_{\text {red }}$, is low, most of the Mn oxide deposited on the sediment is preserved dur- 


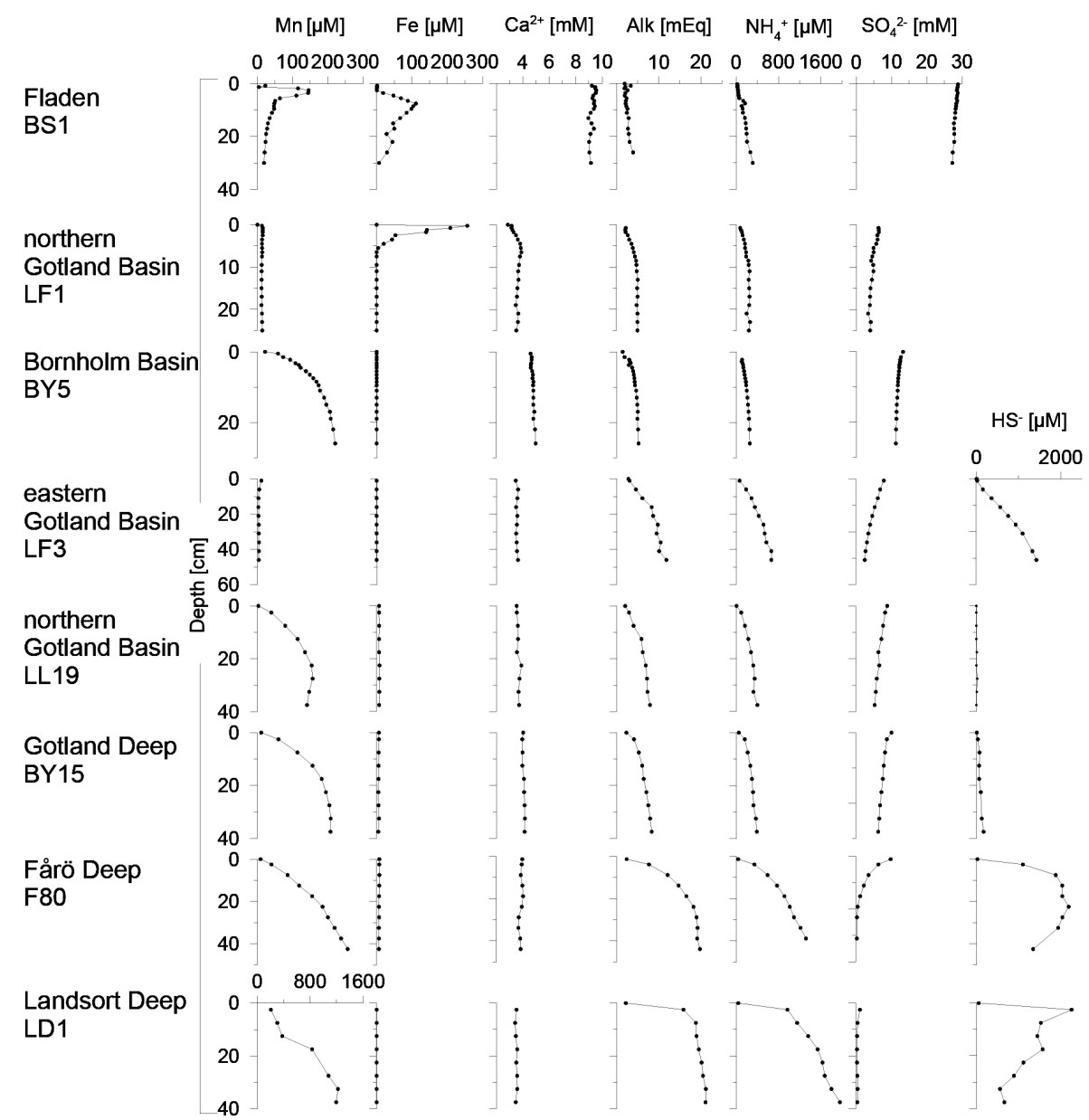

Figure 2. Pore water profiles of dissolved manganese (Mn), iron (Fe), calcium (Ca), alkalinity, ammonium and sulfate for all eight sites, and hydrogen sulfide for the five deepest sites. Note that dissolved Fe is below the detection limit in core LF3 and LD1 and dissolved sulfide is expressed as $\mathrm{HS}^{-}$; some $\mathrm{H}_{2} \mathrm{~S}$ can be present as well.

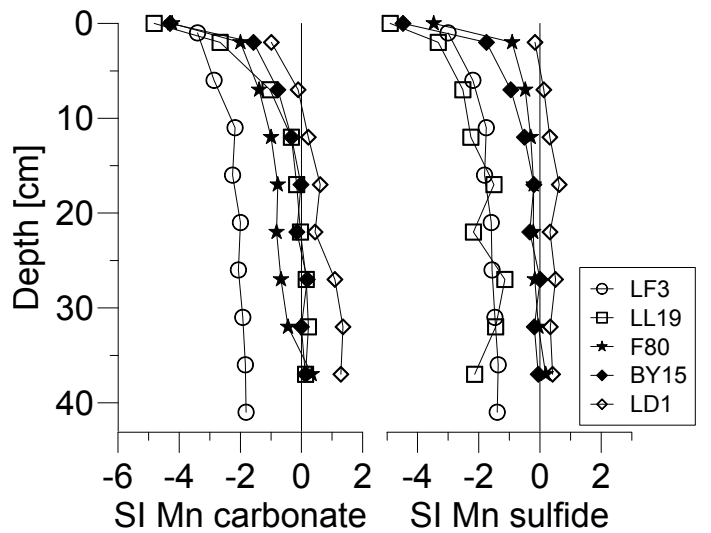

Figure 3. Saturation indices (SI) for $\mathrm{Mn}$ carbonate (here as $\mathrm{Mn}_{0.74} \mathrm{Ca}_{0.26} \mathrm{CO}_{3}$ ) and $\mathrm{Mn}$ sulfide as calculated from the pore water data with PHREEQC.

ing the first 4 months of the simulation. The results show that the more Mn oxide is preserved during the oxic phase, the more Mn carbonate forms during the following anoxic phase, because less dissolved Mn escapes to the overlying water through diffusion. In runs with low values of $k_{\text {red }}, \mathrm{Mn}$ carbonate is mostly formed in the 2-month anoxic phase. At intermediate values of $k_{\text {red }}$, there is also formation of Mn carbonate in the oxic phase. At high values of $k_{\text {red }}$, Mn carbonate formation is negligible. Corresponding changes in integrated amounts of dissolved $\mathrm{Mn}$ in the sediment and benthic fluxes of Mn during the simulations are shown in Supplement 3.

Examples of depth profiles of Mn oxides, dissolved Mn and $\mathrm{Mn}$ carbonate at various key stages of the simulation illustrate the dependence of $\mathrm{Mn}$ carbonate formation on the rate of reduction of $\mathrm{Mn}$ oxides during the oxic phase (Fig. 6c). After 4 months, a large amount of Mn oxides has accumulated in the surface sediment when $k_{\text {red }}$ is equal to $0.1 \mathrm{yr}^{-1}$. Such an enrichment is absent when $k_{\text {red }}$ is $1000 \mathrm{yr}^{-1}$. High dissolved Mn concentrations at the onset of the anoxic phase (shown for 4 months and $8 \mathrm{~h}$ ) and the for- 


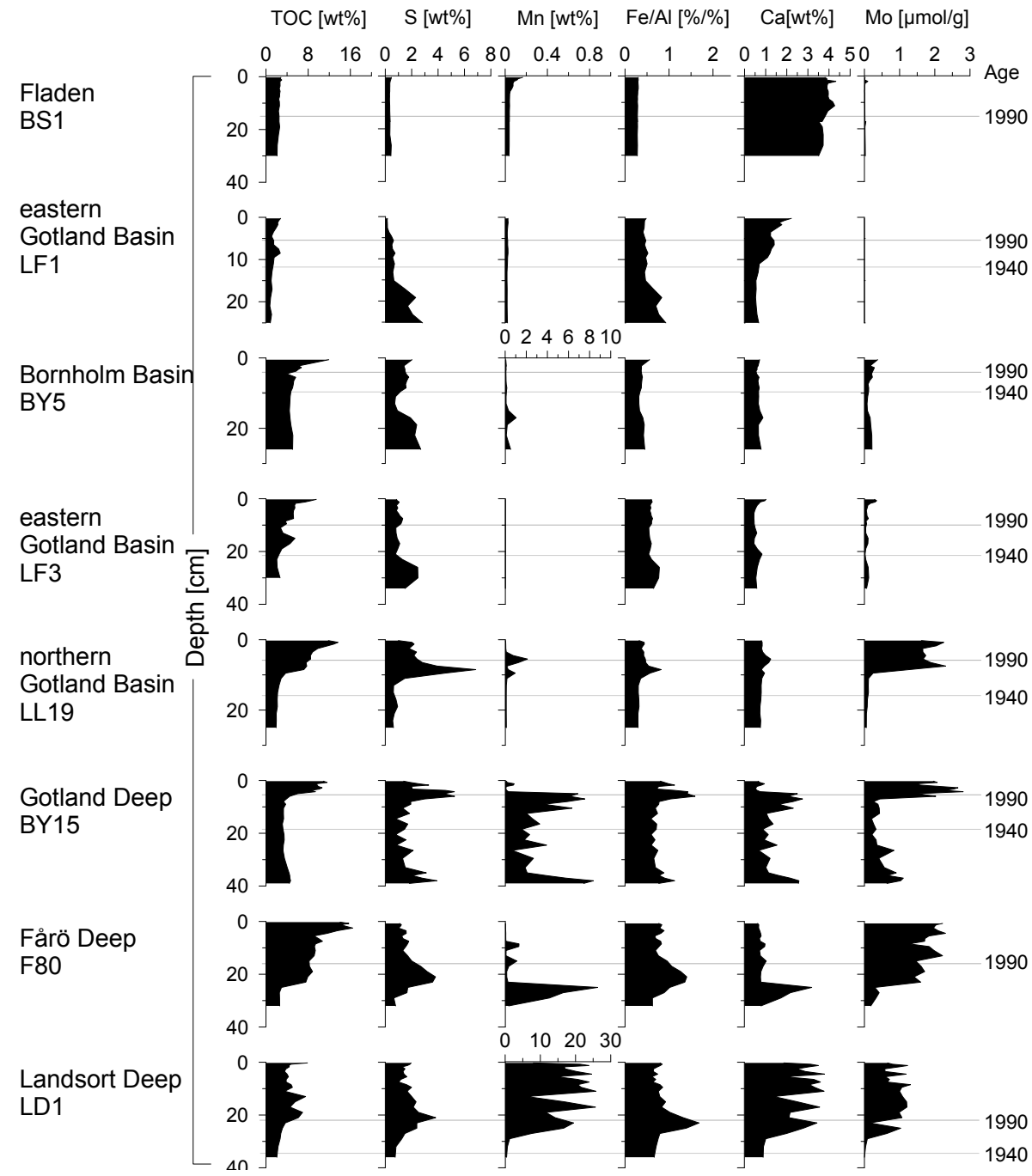

Figure 4. Sediment depth profiles of total organic carbon (TOC), sulfur (S), manganese (Mn), iron to aluminum ratio (Fe / Al), calcium (Ca) and molybdenum for all eight sites. Note the different scale for manganese at Fladen and LF1, and LD1. Grey lines indicate the years 1990 and 1940, based on sediment dating. These date markers are used to demonstrate the variability of sedimentation rates in the study area.

mation of a Mn carbonate-rich layer (shown for the end of the simulation) is restricted to the scenario which allows the $\mathrm{Mn}$ oxides to accumulate. Runs with a higher rate constant for precipitation of $\mathrm{Mn}$ carbonates $\left(k_{\text {prec }}\right)$ lead to more sharply defined peaks in Mn carbonate and more Mn carbonate formation at higher $k_{\text {red }}$ values, but the same trends in fluxes and rates with varying $k_{\text {red }}$ are observed (not shown).

\section{Discussion}

\subsection{Sediment Mn cycling in the Baltic Sea}

Our results indicate major differences in Mn dynamics in the varied depositional settings of the Baltic Sea. Although located in the Kattegat far from the euxinic basins, processes at the Fladen site (Figs. 2 and 3) can be used to illustrate the typical processes at oxic sites. Here, Mn cycling is largely internal to the sediment and the Mn that is released to the pore water at depth mostly reprecipitates upon upward diffusion into the oxic surface sediment. At the hypoxic site in the Bornholm Basin (BY5) there is no clear sediment Mn enrichment but there is release of dissolved Mn to the pore water, presumably due to dissolution of Mn oxides, within the upper $15 \mathrm{~cm}$ of the sediment. At this site, the highest diffusive Mn flux from the sediment to the water column was found (Table 2). At one of the sites on the slope of the eastern Gotland Basin (LF1), there is a significant release of dissolved $\mathrm{Mn}$ to the overlying water but the sediments at this site are low in solid-phase Mn. This suggests that the source of Mn at this site may be of a transient nature. Our results highlight that sediments in hypoxic areas may act as sources of Mn to the water column, with subsequent lateral transfer po- 
A

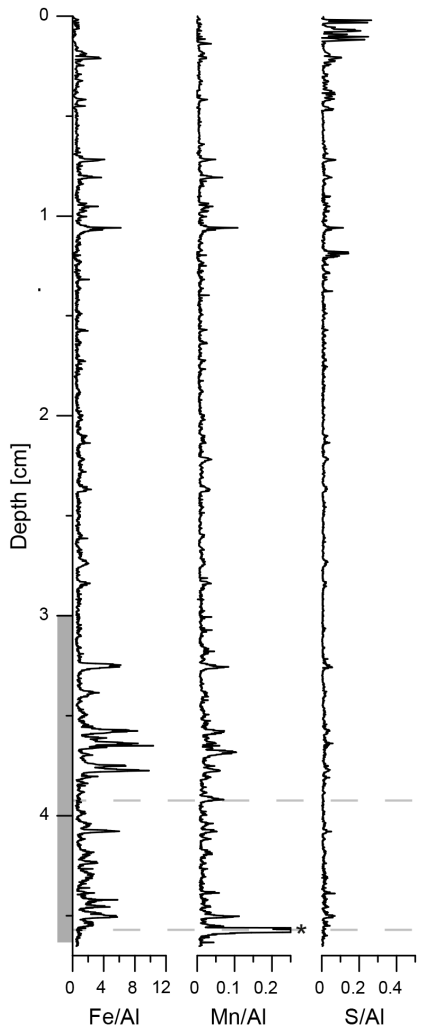

B

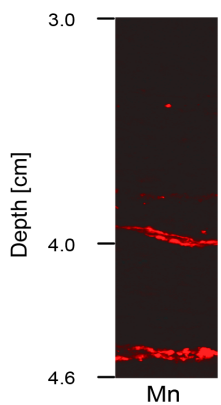

LL19
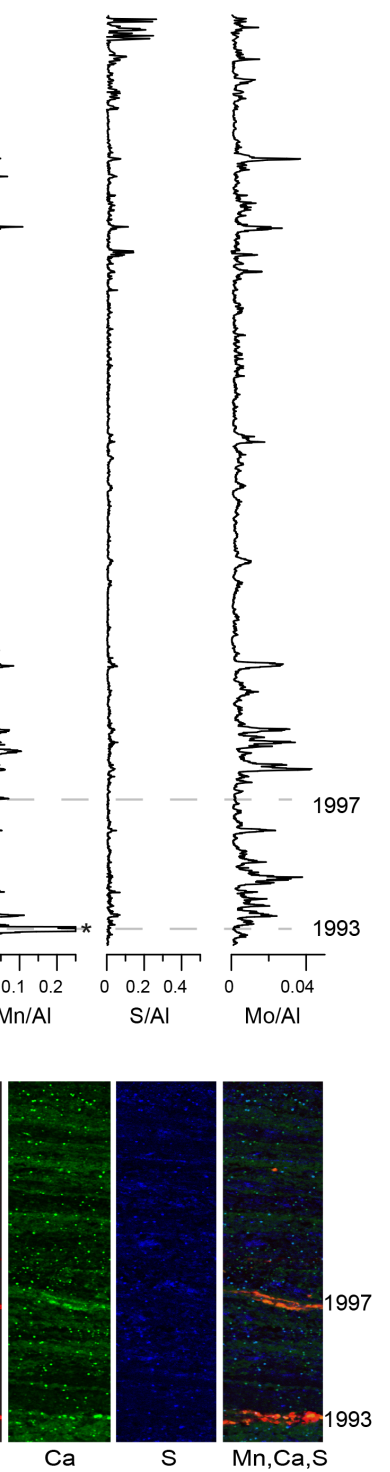
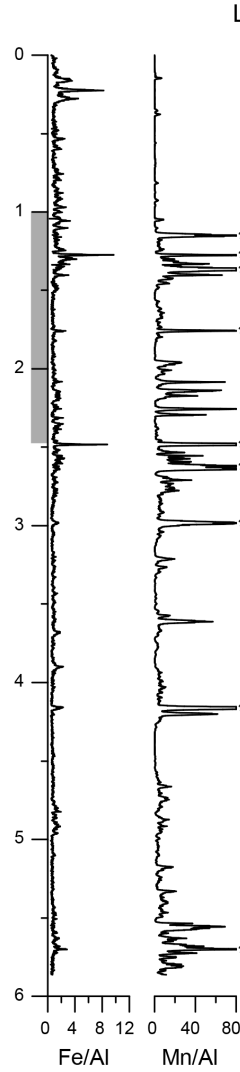

LD1

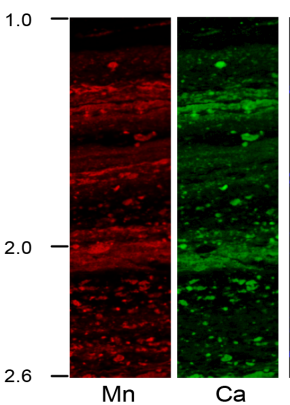

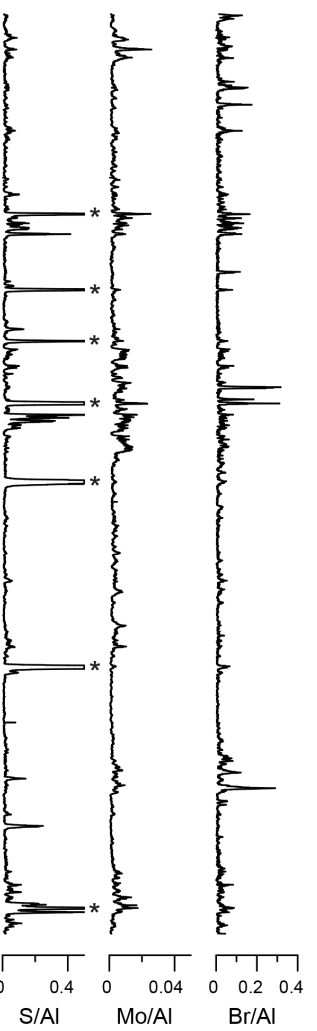

* values exceed scale

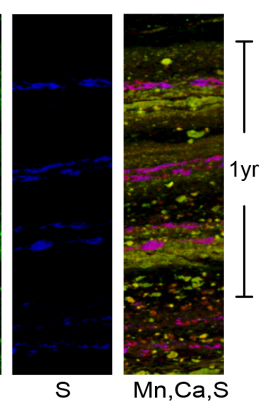

Figure 5. (a) High-resolution elemental profiles of $\mathrm{Fe} / \mathrm{Al}, \mathrm{Mn} / \mathrm{Al}, \mathrm{S} / \mathrm{Al}$, Mo / $\mathrm{Al}$ and $\mathrm{Br} / \mathrm{Al}$ (only LD1) generated by LA-ICP-MS line scanning for resin-embedded surface sediment blocks. Note the difference in absolute values for Mn/Al between LL19 and LD1. The depth scale refers to the compacted sediment in the resin blocks (the total length of wet sediment prior to embedding was $5.5 \mathrm{~cm}$ (LL19) and $11.3 \mathrm{~cm}$ (LD1)). Peaks marked with a * exceed the scale. (b) Compilation of micro-XRF maps for station LL19 and LD1, showing the distribution of manganese (red), calcium (green) and sulfur (blue) at the depths indicated by grey panels in the LA-ICP-MS line scans. Colour intensity within each map is internally proportional to XRF counts, but relative scaling has been modified to highlight features. The fourth picture for each station shows a RGB (red, green, blue) composite of the three elements with orange to yellow colours, indicating a mix of Mn and Ca, and therefore, representing Ca-Mn carbonates. The pink/purple represents a mix of $\mathrm{Mn}$ and $\mathrm{S}$, and hence represents Mn sulfide.

tentially bringing this Mn to the deep basins (Huckriede and Meischner, 1996; Jilbert and Slomp, 2013a; Lyons and Severmann, 2006; Scholz et al., 2013).

The pore water profiles of the four anoxic sites in the various deep basins (LL19, BY15, F80, and LD1) all are indicative of the release of $\mathrm{Mn}$ to the pore water, either from reductive dissolution of Mn oxides or dissolution of Mn carbonates due to undersaturation (e.g. Heiser et al., 2001; Jilbert and
Slomp, 2013a). As a result, diffusive Mn fluxes from the sediment to the water column are also observed at all these deep basin sites where it remains trapped below the redoxcline in the water column. Although reoxidation of the Mn and formation of mixed phases of Mn oxides and Fe(III)-associated phosphates upon upward diffusion of $\mathrm{Mn}$ into the redoxcline occurs (Dellwig et al., 2010; Turnewitsch and Pohl, 2010), 


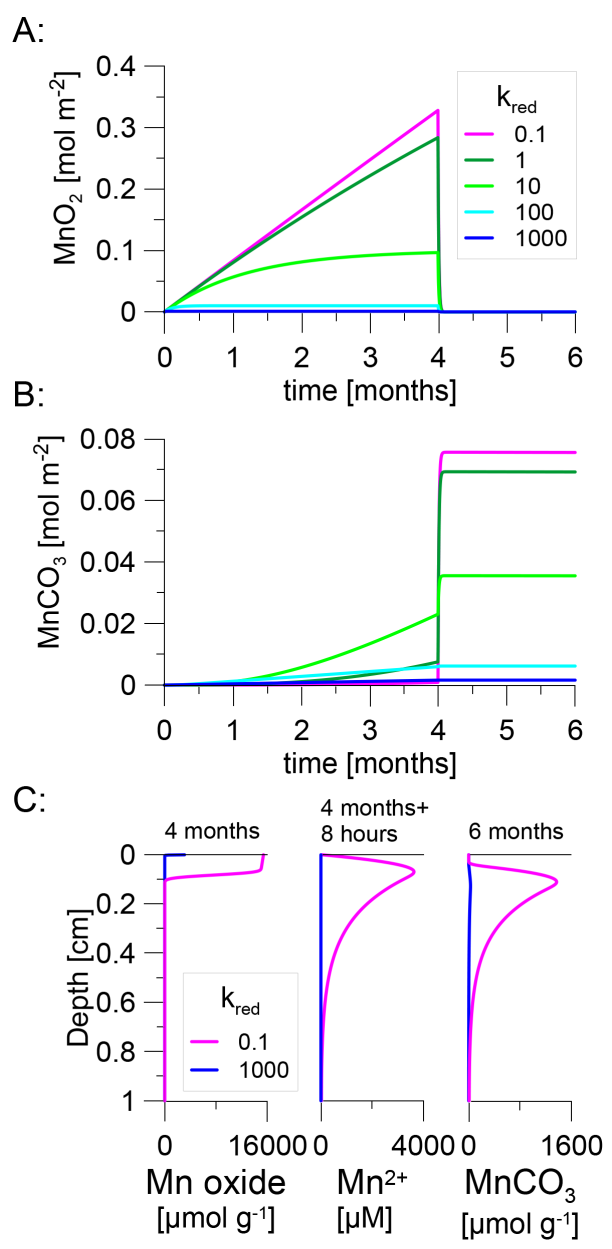

Figure 6. (a) Integrated amount of $\mathrm{Mn}$ oxide and (b) integrated amount of $\mathrm{Mn}$ carbonate in the upper $\mathrm{cm}$ of the sediment (in mol m${ }^{-2}$ ) for the simulation, with $k_{\text {red }}$ being equal to either $0.1,1$, 10,100 or $1000 \mathrm{yr}^{-1}$ for the first 4 months and equal to $1000 \mathrm{yr}^{-1}$ for the last 2 months, as described in the text. (c) Depth profiles of Mn oxide (after 4 months, end of the oxic phase), dissolved Mn (after 4 months and $8 \mathrm{~h}$, directly after the start of the anoxic phase) and $\mathrm{MnCO}_{3}$ (after 6 months) as calculated with the model in the same scenarios as (a) and (b).

sinking of these phases into sulfidic waters leads to subsequent reductive redissolution.

Due to the seasonal and inflow-related changes in redox conditions in the Baltic Sea, the lack of detailed data sets on dissolved Mn concentrations in the water column, and our very limited number of study sites, we cannot accurately estimate the different reservoirs of $\mathrm{Mn}$ and the importance of the present-day source of Mn from sediments overlain by oxic and hypoxic and anoxic bottom waters at the basin scale. Nevertheless, we will attempt to make a rough quantification using the data that are available and will then compare this to estimates from the literature.

Taking an average deep water volume of $2000 \mathrm{~km}^{3}$, average hypoxic area of $47000 \mathrm{~km}^{2}$ (Carstensen et al., 2014), and a deep water concentration of $\mathrm{Mn}$ of $8 \mu \mathrm{M}$ (Löffler et al., 1997 as cited by Heiser et al., 2001), the amount of $\mathrm{Mn}$ in the deep water is estimated at $1.6 \times 10^{10} \mathrm{~mol}$ or $0.33 \mathrm{~mol} \mathrm{~m}^{-2}$. The range of $\mathrm{Mn}$ fluxes estimated in this study ( 0 to $236 \mu \mathrm{mol} \mathrm{m}{ }^{-2} \mathrm{~d}^{-1}$; Table 2) is comparable to benthic fluxes measured with in situ chambers in other areas of the Baltic Sea (e.g. the Gulf of Finland; Pakhomova et al., 2007) as well as those estimated from pore water profiles acquired in the 1990s (e.g. Heiser et al., 2001). If we assume that a flux of ca. $90 \mu \mathrm{mol} \mathrm{m} \mathrm{m}^{-2} \mathrm{~d}^{-1}$ is representative of the sediments overlain by hypoxic and anoxic bottom waters (Table 2; based on the fluxes for LL19, F80 and BY15), we calculate a yearly flux of $0.033 \mathrm{~mol} \mathrm{~m}^{-2}$ from those sediments, which is equivalent to $10 \%$ of the inventory in the water column. In similar calculations, Heiser et al. (2001) estimated the amount of $\mathrm{Mn}$ in the Gotland Deep to be equal to $0.8 \mathrm{~mol} \mathrm{~m}^{-2}$. With our estimate of the benthic flux, this would lead to a contribution of the annual benthic flux of less than $5 \%$. We note, however, that the role of the benthic flux of $\mathrm{Mn}$ from hypoxic sediments will vary spatially and may be biased towards high values because of preferential sampling of sites with a relatively high sediment accumulation rate in most pore water studies. This may explain the 1 order of magnitude lower benthic fluxes of Mn reported for the Gotland Deep area in 1999-2001 of ca. $7-8 \mu \mathrm{mol} \mathrm{m}^{-2} \mathrm{~d}^{-1}$ by Neretin et al. (2003) when compared to those in our study (Table 2).

Benthic fluxes of Mn are also expected to be high upon the re-establishment of bottom water anoxia after an inflow and then decline with time (Neretin et al., 2003). The exact impact of inflows on the oxygenation of the bottom waters in the deep basins of the Baltic Sea varies from site to site, as it depends on the volume and oxygen content of the inflowing water, its pathway and the oxygen concentration in the receiving basin (e.g. Carstensen et al., 2014), with the general flow of water in the deep basins going from the Gotland to the Fårö and the Landsort Deep (Holtermann et al., 2012). For example, the bottom water in the Gotland Deep was free of hydrogen sulfide for 4 months following the inflow of 1993 1994 (Neretin et al., 2003; Yakushev et al., 2011) whereas the Landsort Deep was less affected because the bottom water at the time already contained oxygen (Fig. 7). Using biogeochemical modelling of a typical inflow in the Gotland Deep area, Yakushev et al. (2011) showed that dissolved Mn in the water column was oxidized to Mn oxides and settled to the bottom over a time period of months. Dissolved Mn appeared in the water column again upon the return of bottom water anoxia and steady-state conditions in the water column were established in the model after ca. 1.5 years.

In their study, Yakushev et al. (2011) concluded that sediments play only a minor role as a source of $\mathrm{Mn}$ a few years after an inflow. It is likely that the large pool of $\mathrm{Mn}$ in the water column of the deep basins was mostly released from the formerly oxic sediments during the initial expansion of hypoxia during the 20th century. Based on the fact that apart from the 


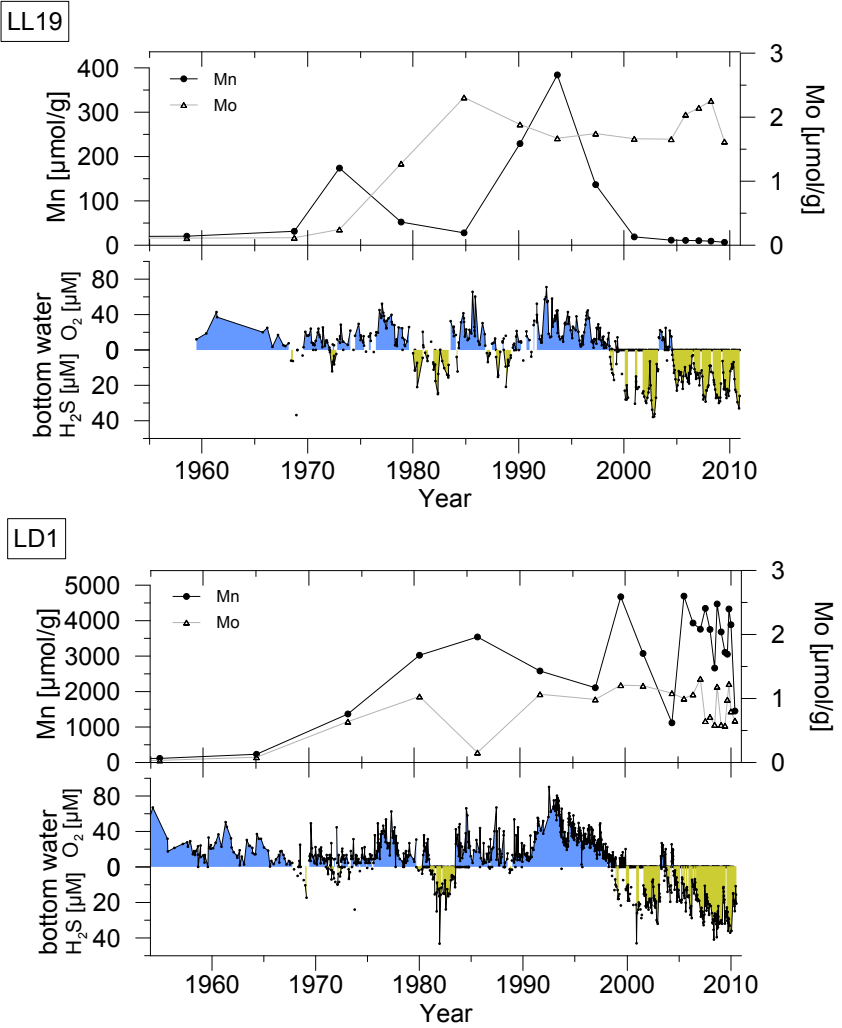

Figure 7. Records of sediment manganese and molybdenum for 1955-2010 for core LL19 and core LD1, and corresponding bottom water oxygen and sulfide concentrations from monitoring data (for LD1 the nearby monitoring station LL23 was used; ICES Dataset on Ocean Hydrography, 2014).

changes in $\mathrm{Mn}$ inventory between inflows, there is no clear trend in water column Mn concentrations in the Baltic Sea with time over recent decades (Pohl and Hennings, 2005), and our observation that the burial of Mn has decreased at most sites (Fig. 4), it is likely that the present-day Mn shuttling from the oxic and hypoxic areas around the deep basins is not as important quantitatively as a source of Mn to the deep basins as it was at the onset of hypoxia early in the 20th century.

Notably, Yakushev et al. (2011) consider Mn(III) besides $\mathrm{Mn}(\mathrm{II})$ in their model for biogeochemical dynamics in the water column in the Gotland Deep. Dellwig et al. (2012) found recently that $\mathrm{Mn}$ (III) is an important component in the water column Mn cycle in the Landsort Deep but not in the Gotland Deep. Further work is required to elucidate the potential importance of this finding to Mn dynamics in the Baltic Sea, its impact on other biogeochemical cycles (e.g. Pakhomova and Yakushev, 2013), its role in the sediments and impacts on Mn sequestration (e.g. Madison et al., 2011). Field studies of Mn dynamics in the water column and sediment during and directly after an inflow would be of particular value.

\subsection{Manganese sequestration in the anoxic basins}

Formation of Mn-bearing carbonates in the Gotland Basin and Landsort Deep is generally described as being ubiquitous after inflows (e.g. Jakobsen and Postma, 1989). We observe such Mn carbonate enrichments in all our deep basin cores, with the magnitude of the enrichment increasing with water depth (Fig. 4). We suggest that this water depth effect between the deep basin sites is due to increased focusing of particulate Mn oxides precipitated during inflow events with water depth, combined with a high alkalinity in the deep basins linked to organic matter degradation by sulfate reduction. Increased focusing of Mn oxides with water depth has been observed in other marine systems (e.g. Slomp et al., 1997) and a high alkalinity in sulfate-bearing organic-rich sediments overlain by an anoxic water column is typically linked to organic matter degradation through sulfate reduction (Berner et al., 1970).

Our microanalysis results show that the Mn carbonate enrichments at site LL19 are highly laminar in character, implying rapid precipitation at or near the sediment-water interface. Furthermore, these Mn carbonate enrichments occur independently of enrichments in Mo and S. Sedimentary Mo can be used as a proxy for sulfidic conditions close to the sediment-water interface, due to the conversion of seawater oxymolybdate to particle-reactive thiomolybdate in the presence of hydrogen sulfide (Erickson and Helz, 2000). Although the ultimate burial phase of Mo in sulfidic sediments is still debated (e.g. Helz et al., 2011), Mo concentrations have successfully been used to reconstruct the redox history of the bottom water in restricted coastal basins (Adelson et al., 2001; Jilbert and Slomp, 2013a). Sulfur enrichments in sediments are typically associated with Fe sulfides. These can form as the result of reduction of $\mathrm{Fe}$ (III) oxides with sulfide or organic matter (Boesen and Postma, 1988), and thus Fe sulphides can also be indicative of sulfidic conditions close to the sediment-water interface. The independence of these Mn enrichments from those of Mo and S suggests relatively oxic conditions at the time of Mn deposition. Both lines of evidence support the interpretation of $\mathrm{Mn}$ carbonate precipitation following inflow events (Sternbeck and Sohlenius, 1997). Our age model suggests that the two pronounced Mn carbonate layers at the base of the surfacesediment resin-embedded block (Fig. 5) correspond to inflows in 1993 and 1997 (Matthäus and Schinke, 1999).

Mn enrichments at the Landsort Deep site LD1 occur more frequently when compared to other deep basin sites (Fig. 4), as observed in earlier work (Lepland and Stevens, 1998). In the Landsort Deep, Lepland and Stevens (1998) attributed the enrichments to the relatively high alkalinity. Our pore water results show that alkalinity is similar to that in the Fårö Deep (F80), but the pore water Mn concentrations at the Landsort Deep site are much higher than elsewhere ( $>1 \mathrm{mM}$ vs. $<0.26 \mathrm{mM}$ of Mn). This may be related to the fact that the Landsort Deep is the deepest basin in the Baltic Sea and its 
geometry makes it an excellent sediment trap. Indeed sediment deposition rates at the Landsort Deep are much higher than in the other deeps (Lepland and Stevens, 1998; Mort et al., 2010), perhaps as much as 6 times higher (Expedition 347 Scientists, 2014). Sediment focusing is also expected to lead to a higher input of organic matter and Mn oxides to this basin. Given that rates of mineral dissolution are expected to depend on the amount of material present, corresponding rates of input and dissolution of $\mathrm{Mn}$ oxide minerals in the sediment are likely higher in the Landsort Deep than at other sites. Thus, we suggest that differences in focusing of the sediment may explain the observed differences in pore water chemistry and Mn sequestration. The differences in pore water chemistry will also likely impact the exact solid phases formed in the sediments of the various deep basins.

The high-resolution analyses for the Landsort Deep site (LD1) also show that, besides Mn carbonate enrichments, there are several distinct layers of Mn sulfide in the surface sediments (Fig. 5). These appear to coincide with enrichments in Mo, suggesting formation of Mn sulfides during intervals of more reducing conditions (Mort et al., 2010). Furthermore, we observe simultaneous enrichments of $\mathrm{Br}$ (Fig. 5), which suggests higher organic carbon contents (Ziegler et al., 2008). These results could imply that increased rates of sulfate reduction linked to elevated inputs of organic material to the sediments drive the formation of $\mathrm{Mn}$ sulfide by contributing to an excess of sulfide over Fe. We note that the interval presented in the XRF map covers only a few years of sediment accumulation, possibly suggesting rapid changes in Mn mineralogy in response to seasonal variability of the organic matter flux (Fig. 5). Primary productivity in the Baltic Sea is known to vary seasonally (Bianchi et al., 2002; Fennel, 1995). Further work is required to determine the mechanisms of MnS formation conclusively. While the presence of $\mathrm{MnS}$ has been shown for the earlier anoxic time intervals in the Baltic (Böttcher and Huckriede, 1997; Lepland and Stevens, 1998), this is the first time Mn sulfides are reported for such near-surface sediments in the Baltic Sea.

The contrasting controls on Mn mineral formation in the Landsort Deep, compared to the other deep basin sites, are further illustrated by a comparison of the trends in total $\mathrm{Mn}$ and Mo concentrations (Fig. 4) with measured bottom water oxygen concentrations for the period 1955 to 2010 (ICES Dataset on Ocean Hydrography 2014) for sites in the northern Gotland Basin (LL19) and the Landsort Deep (LD1) (Fig. 7). At site LL19, Mn enrichments in the sediments coincide with low values of Mo in the sediment and inflows of oxygenated water. This suggests that Mn burial is enhanced under more oxygenated bottom water conditions. At LD1, in contrast, high Mn contents are observed from 1965 onwards, independent of inflows, with the highest Mn values coinciding with periods with the highest sulfide concentrations that occur in particular since the year 2000. This supports our hypothesis that the formation of $\mathrm{Mn}$ carbonate minerals in the
Landsort Deep is not always related to inflows and that the Mn oxide supply is higher and more continuous when compared to the other basins, due to the much stronger sediment focusing related to the peculiar basin geometry.

\subsection{Changes in Mn burial linked to expanding hypoxia}

Strikingly, the more reducing conditions in the Gotland Basin (LL19, BY15) and Fårö Deep sites (F80) over the past decades, as recorded in the Mo profiles (Figs. 4 and 7), are accompanied by a strong reduction in sediment Mn burial. Given the suggested link between Mn burial and inflows, it is important to assess the occurrence of these inflows. During the past 2 decades, there were two major $(1993,2003)$ and several minor inflow events (e.g. 1997) into the Baltic Sea. The event in 1993 was one of the strongest in the last 60 years (Matthäus et al., 2008) and the inflow of 2003 (Feistel et al., 2003) was weaker but still significant enough to reoxygenate the bottom water of the deep basins (Fig. 7). Nevertheless, at LL19, Mn sequestration in the sediment between 2000 and 2010 has been negligible and the inflow in 2003 is not recorded as a Mn carbonate enrichment (Fig. 7), whereas, in the high-resolution geochemical analyses, Mn layers are clearly visible in both the LA-ICP-MS and micro-XRF scans (Fig. 5) and can be linked to the inflows of 1993 and 1997. A similar "missing" Mn carbonate layer was observed by Heiser et al. (2001) in the Gotland Deep and attributed to redissolution of Mn carbonate linked to resuspension events and mixing of the sediment into unsaturated bottom waters, but our cores were clearly laminated and the ${ }^{210} \mathrm{~Pb}$ profiles also show no evidence for mixing. We therefore conclude that with the increased hypoxia and euxinia in the Baltic Sea, Mn oxides are no longer converted to stable Mn carbonates following inflows.

The formation of Mn carbonates in Baltic Sea sediments is typically believed to be induced by the high alkalinity linked to organic matter degradation combined with high dissolved Mn concentrations in the surface sediment. These high dissolved Mn concentrations are thought to be the result of reductive dissolution of $\mathrm{Mn}$ oxides that have formed at the sediment-water interface directly following an inflow of oxygenated North Sea water. When hypoxia is re-established and the oxides are dissolved (Lepland and Stevens, 1998), supersaturation with respect to Mn carbonates is assumed to be reached in the surface sediment and not only at depths below ca. $5-10 \mathrm{~cm}$ (Fig. 3). What can inhibit the formation of these Mn carbonates? One possibility is that at high pore water sulfide concentrations, Mn sulfides form instead of Mn carbonates, but given that there is negligible Mn enrichment in the upper sediments of F80, BY15 and LL19 today, we can exclude that possibility. Mn carbonate formation could be reduced if alkalinity declined, but alkalinity in the bottom waters of the Gotland Deep has in fact increased recently (e.g. Ulfsbo et al., 2011), possibly due to higher rates of anaerobic mineralization linked to eutrophication (Gustafsson et 
al., 2014). High phosphate concentrations in the surface sediment may potentially negatively affect the rate of $\mathrm{Mn}$ carbonate formation (Mucci, 2004), but there is no evidence for a significant rise in dissolved phosphate in the pore water of Gotland Basin sediments over the past decades (e.g. Carman and Rahm, 1997; Hille et al., 2005; Jilbert et al., 2011). Alternatively, we hypothesize that the Mn oxides that are formed following modern inflow events might be reductively dissolved faster than previously. As a consequence, the dissolved $\mathrm{Mn}$ released from the oxides could then escape to the overlying water instead of being precipitated in the form of Mn carbonate. This hypothesis is consistent with the results of the simple diagenetic model where high rates of $\mathrm{Mn}$ oxide reduction lead to less Mn carbonate formation (Fig. 6).

There are multiple possible reductants for Mn oxides in marine sediments, including sulfide, $\mathrm{Fe}$ (II) (e.g. Canfield and Thamdrup, 2009), $\mathrm{NH}_{4}^{+}$(e.g. Luther et al., 1997) and $\mathrm{CH}_{4}$ (Beal et al., 2009), with the role of the latter two reductants in marine sediments still being debated. Given that the dissolved $\mathrm{Fe}$ and $\mathrm{CH}_{4}$ concentrations in the pore waters of the surface sediments of the Gotland Basin area are negligible, these constituents are unlikely to play an important role as a reductant for Mn oxides in the northern Gotland Basin (LL19), Fårö Deep (F80) and Gotland Deep (BY15) sites. Furthermore, there is no evidence for a major recent change in pore water $\mathrm{CH}_{4}$ concentrations in the surface sediments. There is evidence, however, for a recent rise in the bottom water sulfide concentrations in the deep basins of the Baltic Sea (Fig. 7) linked to eutrophication (Carstensen et al., 2014). As shown for the northern Gotland Basin site (LL19), the more persistent presence of high concentrations of bottom water sulfide and enrichments in sediment Mo coincide with the decline in Mn in the sediment (Fig. 7).

We hypothesize that Mn oxides that are formed following modern inflow events and that are deposited on the seafloor (Heiser et al., 2001) are no longer being converted to Mn carbonates because of higher pore water sulfide concentrations and the rapid onset of sulfidic conditions in the overlying waters. These higher sulfide concentrations are likely the direct result of increased sulfate reduction driven by the ongoing rise in productivity in the Baltic Sea (Gustafsson et al., 2012, 2014; Carstensen et al, 2014). The observed decline in $\mathrm{Fe} / \mathrm{Al}$ at our deep basin sites (Fig. 3) suggests more muted shuttling of Fe oxides from shelves to the deeps linked to the expanding hypoxia (e.g. Scholz et al., 2014) which may have reduced the buffer capacity of the sediments for sulfide (e.g. Diaz and Rosenberg, 2008).

The rate of reduction of $\mathrm{Mn}$ oxides with sulfides is assumed to linearly depend on the concentration of sulfide according to the following rate law (Wang and Van Cappellen, 1996):

$R=k C_{\mathrm{TS}} C_{\mathrm{Mn}_{\text {oxides }}}$,

where $k$ is a rate constant (with a value $<10^{8} \mathrm{yr}^{-1}$ ) and $C_{\mathrm{TS}}$ stands for the total sulfide concentration, i.e. the sum of the concentrations of $\mathrm{H}_{2} \mathrm{~S}$ and $\mathrm{HS}^{-}$(in $\mathrm{M}$ ). In our modelling approach, the rate law for this process is assumed equal to

$R=k_{\mathrm{red}} C_{\mathrm{Mn}_{\text {oxides }}}$.

Thus, if sulfide is the reductant, $k_{\text {red }}$ can be assumed to be equivalent to the product of $k$ and $C_{\mathrm{TS}}$. Sulfide will be absent in oxygenated pore waters, i.e. can be below $1 \mu \mathrm{M}$ in the surface sediment, but also can range up to 1.1 to $2.2 \mathrm{mM}$ as observed at sites F80 and LD1 (Fig. 2; Supplement 2). Corresponding $k_{\text {red }}$ values for surface sediments in the Baltic Sea would then be expected to range over 3-4 orders of magnitude and stay below $10^{5} \mathrm{yr}^{-1}$, which is consistent with our assumptions. Mn carbonate formation is found to critically depend on the value of $k_{\text {red }}$ (Fig. 6). Although we are aware that factors other than the availability of $\mathrm{Mn}$ are also critical to Mn carbonate formation, these model results support our suggestion that a recent rise in the pore water and bottom water sulfide concentrations may have made the surface sediments more hostile to the preservation of $\mathrm{Mn}$ oxide after an inflow and might contribute to their reduction. Consequently, more dissolved Mn could then escape to the overlying water instead of being precipitated in the form of Mn carbonate, explaining the lack of recent Mn enrichments.

\subsection{Implications for Mn as a redox proxy}

In the classic model of Calvert and Pedersen (1993), Mn enrichments in sediments are indicative of either permanent or temporary oxygenation of bottom waters. Sediments of permanently anoxic basins, in contrast, are assumed to have no authigenic Mn enrichments because there is no effective mechanism to concentrate $\mathrm{Mn}$ oxides. Our results for the Gotland Deep area indicate that the temporary oxygenation of the basin linked to inflows is no longer recorded as a $\mathrm{Mn}$ enrichment in the recent sediment when hypoxia becomes basin-wide. Thus, a decline in Mn burial (or a complete lack of $\mathrm{Mn}$ ) in geological deposits in combination with indicators for water column euxinia, such as elevated Mo contents, may point towards expanding hypoxia, but does not exclude temporary oxygenation events. Strikingly, only very little $\mathrm{Mn}$ was buried at sites F80 and LL19 during the previous period of hypoxia in the Baltic Sea during the Medieval Climate Anomaly (Jilbert and Slomp, 2013b) as well as at the end of the Holocene Thermal Maximum at site LL19 (Lenz et al., 2014). It is believed that hypoxia was equally intense and widespread in the basin at the time as it is today. Our results for the Landsort Deep suggests that Mn enrichments may also form frequently in an anoxic basin as Mn carbonates and sulfides if the input of $\mathrm{Mn}$ from the surrounding area is exceptionally high due to sediment focusing. Mn enrichments in geological deposits can be indicative of both oxic and anoxic depositional environments, emphasizing the need for multiple redox proxies. 


\section{Conclusions}

We show that the most recent sediments in the Fårö Deep and Gotland Deep contain low concentrations of Mn near the sediment surface. We hypothesize that this is due to the expansion of the area with hypoxic bottom waters and the development of more continuous bottom water euxinia over the past decades, linked to ongoing eutrophication and possibly due to the reduced input of Fe oxides that can act as a sink for sulfide. The high ambient sulfide concentrations in the sediment and water column after an inflow event are thought to be more conducive to faster dissolution of Mn oxides, leading to more loss of dissolved $\mathrm{Mn}$ to the water column and less formation of Mn carbonate. Our hypothesis is supported by the results of a simple diagenetic model for $\mathrm{Mn}$. It is also consistent with the general interpretation of sediment records of $\mathrm{Mn}$ in paleoceanography and the use of $\mathrm{Mn}$ as a redox proxy, where the absence of Mn carbonates in sediments is assumed to be indicative of euxinic bottom waters (e.g. Calvert and Pedersen, 1993). In the Landsort Deep, in contrast, Mn sulfides and carbonates are still being precipitated. This could be due to strong focusing of Mn-rich sediment particles and high rates of sediment accumulation in the Landsort Deep. Our results indicate that sediment Mn carbonates in the other deep basins of the Baltic Sea no longer reliably and consistently record inflows of oxygenated North Sea water. This has implications for the use of Mn enrichments as a redox proxy when analysing geological deposits.

\section{The Supplement related to this article is available online at doi:10.5194/bg-12-4875-2015-supplement.}

Acknowledgements. This work was funded by grants from the Baltic Sea 2020 foundation, the Netherlands Organisation for Scientific Research (NWO Vidi and Vici), Utrecht University (via UU short stay fellowship 2011), the EU-BONUS project HYPER and the European Research Council under the European Community's Seventh Framework Programme for ERC Starting Grant \#278364. M. Wolthers acknowledges Natural Environment Research Council [fellowship \#NE/J018856/1]. We thank the captain and crew of RV Skagerrak (2007), RV Aranda (2009), RV Heincke (2010) and RV Pelagia (2011) and all participants of the cruises for their assistance with the field work. We thank Simon Veldhuijzen for his contribution to the analyses for site F80.

Edited by: K. Fennel

\section{References}

Adelson, J. M., Helz, G. R., and Miller, C. V.: Reconstructing the rise of recent coastal anoxia; molybdenum in Chesapeake Bay sediments, Geochim. Cosmochim. Acta, 65, 237-252, 2001.
Ahl, T.: River Discharges of $\mathrm{Fe}, \mathrm{Mn}, \mathrm{Cu}, \mathrm{Zn}$, and $\mathrm{Pb}$ into the Baltic Sea from Sweden, Ambio Special Report, 219-228, 1977.

Appleby, P. and Oldfield, F.: The assessment of ${ }^{210} \mathrm{~Pb}$ data from sites with varying sediment accumulation rates, Hydrobiology, 103, 29-35, 1983.

Beal, E. J., House, C. H., and Orphan, V. J.: Manganese- and IronDependent Marine Methane Oxidation, Science, 325, 184-187, 2009.

Berner, R. A.: Early diagenesis: A theoretical approach, Princeton University Press, 1980.

Berner, R. A., Scott, M. R., and Thomlinson, C.: Carbonate alkalinity in the pore waters of anoxic marine sediments, Limno. Oceanogr., 15, 544-549, 1970.

Bianchi, T. S., Rolff, C., Widbom, B., and Elmgren, R.: Phytoplankton Pigments in Baltic Sea Seston and Sediments: Seasonal Variability, Fluxes, and Transformations, Estuar. Coast. Shelf Sci., 55, 369-383, 2002.

Boesen, C. and Postma, D.: Pyrite formation in anoxic environments of the Baltic, Am. J. Sci., 288, 575-603, 1988.

Böttcher, M. E. and Huckriede, H.: First occurrence and stable isotope composition of authigenic $\gamma-\mathrm{MnS}$ in the central Gotland Deep (Baltic Sea), Mar. Geol., 137, 201-205, 1997.

Boudreau, B. P.: Diagenetic models and their implementation: modelling transport and reactions in aquatic sediments, Springer Berlin, 1997.

Cai, W.-J and Reiners, C. E.: The development of $p \mathrm{H}$ and $p \mathrm{CO}_{2}$ microelectrodes for studying the carbonate chemistry of pore waters near the sediment-water interface, Limnol. Oceanogr., 38, 1762 $1773,1993$.

Calvert, S. and Pedersen, T.: Geochemistry of recent oxic and anoxic marine sediments: Implications for the geological record, Mar. Geol., 113, 67-88, 1993.

Calvert, S. and Pedersen, T.: Sedimentary geochemistry of manganese; implications for the environment of formation of manganiferous black shales, Econ. Geol., 91, 36-47, 1996.

Canfield, D. E. and Thamdrup, B.: Towards a consistent classification scheme for geochemical environments, or, why we wish the term "suboxic" would go away, Geobiology, 7, 385-392, 2009.

Carman, R. and Rahm, L.: Early diagenesis and chemical characteristics of interstitial water and sediments in the deep deposition bottoms of the Baltic proper, J. Sea Res., 37, 25-47, 1997.

Carstensen, J., Andersen, J. H., Gustafsson, B. G., and Conley, D. J.: Deoxygenation of the Baltic Sea during the last century, PNAS, 111, 5628-5633, 2014

Conley, D. J., Björck, S., Bonsdorff, E., Carstensen, J., Destouni, G., Gustafsson, B. G., Hietanen, S., Kortekaas, M., Kuosa, H., Meier, H. E., Müller-Karulis, B., Nordberg, K., Norkko, A., Nürnberg, G., Pitkänen, H., Rabalais, N. N., Rosenberg, R., Savchuk, O P., Slomp, C. P., Voss, M., Wulff, F., and Zillen, L.: Hypoxiarelated processes in the Baltic Sea, Environ. Sci. Technol., 43 , 3412-3420, 2009

Dellwig, O., Leipe, T., März, C., Glockzin, M., Pollehne, F., Schnetger, B., Yakushev, E. V., Böttcher, M. E., and Brumsack, H.-J.: A new particulate $\mathrm{Mn}-\mathrm{Fe}-\mathrm{P}$-shuttle at the redoxcline of anoxic basins, Geochim. Cosmochim. Acta, 74, 7100-7115, 2010.

Dellwig, O., Schnetger, B., Brumsack, H.-J., Grossart, H.-P., and Umlauf, L.: Dissolved reactive manganese at pelagic redoxclines (part II): Hydrodynamic conditions for accumulation, J. Mar. Syst., 90, 31-41, 2012. 
Diaz, R. J. and Rosenberg, R.: Marine benthic hypoxia: a review of its ecological effects and the behavioural responses of benthic macrofauna, Oceanography and marine biology, Ann. Rev., 33, 245-203, 1995.

Emerson, S., Jacobs, L., and Tebo, B.: The Behavior of Trace Metals in Marine Anoxic Waters: Solubilities at the Oxygen-Hydrogen Sulfide Interface, in: Trace Metals in Sea Water, edited by: Wong, C. S., Boyle, E., Bruland, K., Burton, J. D., and Goldberg, E., NATO Conference Series, Springer US, 579-608, 1983.

Erickson, B. E. and Helz, G. R.: Molybdenum(VI) speciation in sulfidic waters: Stability and lability of thiomolybdates, Geochim. Cosmochim. Acta, 64, 1149-1158, 2000.

Expedition 347 Scientists: Baltic Sea Basin Paleoenvironment: paleoenvironmental evolution of the Baltic Sea Basin through the last glacial cycle, IODP Prel. Rept., 347, doi:10.2204/iodp.pr.347.2014, 2014.

Feistel, R., Nausch, G., Mohrholz, V., Lysiak-Pastuszak, E., Seifert, T., Matthaus, W., Kruger, S., and Hansen, I. S.: Warm waters of summer 2002 in the deep Baltic Proper, Oceanologia, 45, 571592, 2003.

Fennel, W.: A model of the yearly cycle of nutrients and plankton in the Baltic Sea, J. Mar. Syst., 6, 313-329, 1995.

Fonselius, S. and Valderrama, J.: One hundred years of hydrographic measurements in the Baltic Sea, J. Sea Res., 49, 229241, 2003.

Gustafsson, B. G., Schenk, F., Blenckner, T., Eilola, K., Meier, H. M., Müller-Karulis, B., Neumann, T., Ruoho-Airola, T., Savchuk, O. P., and Zorita, E.: Reconstructing the development of Baltic Sea eutrophication 1850-2006, Ambio, 41, 534-548, 2012.

Gustafsson, E., Wällstedt, T., Humborg, C., Mörth, C.-M., and Gustafsson, B. G.: External total alkalinity loads versus internal generation: The influence of nonriverine alkalinity sources in the Baltic Sea, Global Biogeochem. Cy., 28, 1358-1370,, 2014.

Heiser, U., Neumann, T., Scholten, J., and Stüben, D.: Recycling of manganese from anoxic sediments in stagnant basins by seawater inflow: A study of surface sediments from the Gotland Basin, Baltic Sea, Mar. Geol., 177, 151-166, 2001.

Helz, G. R., Bura-Nakić, E., Mikac, N., and Ciglenečki, I.: New model for molybdenum behavior in euxinic waters, Chem. Geol., 284, 323-332, 2011.

Hennekam, R., Jilbert, T., Mason, P. R. D., de Lange, G. J., and Reichart, G-J.: High-resolution line-scan analysis of resinembedded sediments using laser ablation-inductively coupled plasma-mass spectrometry (LA-ICP-MS), Chem Geol, 403, 42$51,2015$.

Hille, S., Nausch, G., and Leipe, T.: Sedimentary deposition and reflux of phosphorus $(\mathrm{P})$ in the Eastern Gotland Basin and their coupling with $\mathrm{P}$ concentrations in the water column, Oceanologia, 47, 663-679, 2005.

Holtermann, P. L. and Umlauf, L.: The Baltic Sea Tracer Release Experiment: 2. Mixing processes, J. Geophys. Res.-Oceans, 117, C01022, doi:10.1029/2011JC007445, 2012.

Huckriede, H. and Meischner, D.: Origin and environment of manganese-rich sediments within black-shale basins, Geochim. Cosmochim. Acta, 60, 1399-1413, 1996.

Huerta-Diaz, M. A. and Morse, J. W.: Pyritization of trace metals in anoxic marine sediments, Geochim. Cosmochim. Acta, 56, 2681-2702, 1992.
ICES Dataset on Ocean Hydrography. The International Council for the Exploration of the Sea, Copenhagen, 2014.

Jacobs, L., Emerson, S., and Skei, J.: Partitioning and transport of metals across the $\mathrm{O}_{2} / \mathrm{H}_{2} \mathrm{~S}$ interface in a permanently anoxic basin: Framvaren Fjord, Norway, Geochim. Cosmochim. Acta, 49, 1433-1444, 1985.

Jakobsen, R. and Postma, D.: Formation and solid solution behavior of Ca-rhodochrosites in marine muds of the Baltic deeps, Geochim. Cosmochim. Acta, 53, 2639-2648, 1989.

Jilbert, T. and Slomp, C. P.: Iron and manganese shuttles control the formation of authigenic phosphorus minerals in the euxinic basins of the Baltic Sea, Geochim. Cosmochim. Acta, 107, 155169, 2013a.

Jilbert, T. and Slomp, C. P.: Rapid high-amplitude variability in Baltic Sea hypoxia during the Holocene, Geology, 41, 11831186, 2013b

Jilbert, T., Slomp, C. P., Gustafsson, B. G., and Boer, W.: Beyond the Fe-P-redox connection: preferential regeneration of phosphorus from organic matter as a key control on Baltic Sea nutrient cycles, Biogeosciences, 8, 1699-1720, doi:10.5194/bg-8-16992011, 2011.

Jochum, K. P., Weis, U., Stoll, B., Kuzmin, D., Yang, Q., Raczek, I., Jacob, D. E., Stracke, A., Birbaum, K., and Frick, D. A.: Determination of reference values for NIST SRM 610-617 glasses following ISO guidelines, Geostand. Geoanal. Res., 35, 397-429, 2011.

Jones, C., Crowe, S. A., Sturm, A., Leslie, K. L., MacLean, L. C. W., Katsev, S., Henny, C., Fowle, D. A., and Canfield, D. E.: Biogeochemistry of manganese in ferruginous Lake Matano, Indonesia, Biogeosciences, 8, 2977-2991, doi:10.5194/bg-8-29772011, 2011.

Katsikopoulos, D., Fernández-González, A., and Prieto, M.: Precipitation and mixing properties of the "disordered" $(\mathrm{Mn}, \mathrm{Ca}) \mathrm{CO}_{3}$ solid solution, Geochim. Cosmochim. Acta 73, 6147-6161, 2009.

Kulik, D. A., Kersten, M., Heiser, U., and Neumann, T.: Application of Gibbs Energy Minimization to Model Early-Diagenetic Solid-Solution Aqueous-Solution Equilibria Involving Authigenic Rhodochrosites in Anoxic Baltic Sea Sediments, Aquat. Geochem., 6, 147-199, 2000.

Lenz, C., Behrends, T., Jilbert, T., Silveira, M., and Slomp, C. P.: Redox-dependent changes in manganese speciation in Baltic Sea sediments from the Holocene Thermal Maximum: An EXAFS, XANES and LA-ICP-MS study, Chem. Geol., 370, 49-57, 2014.

Lepland, A. and Stevens, R. L.: Manganese authigenesis in the Landsort Deep, Baltic Sea, Mar. Geol., 151, 1-25, 1998.

Löffler, A.: The importance of particles for the distribution of trace metals in the Baltic Sea, especially under changing redox conditions in the central Baltic deep basins., Meereswissenschaftliche Berichte Warnemünde, 27, 153 pp., 1997.

Luther III, G. W., Rickard, D. T., Theberge, S., and Olroyd, A.: Determination of metal (bi) sulfide stability constants of $\mathrm{Mn}^{2+}$, $\mathrm{Fe}^{2+}, \mathrm{Co}^{2+}, \mathrm{Ni}^{2+}, \mathrm{Cu}^{2+}$, and $\mathrm{Zn}^{2+}$ by voltammetric methods, Environ. Sci. Technol., 30, 671-679, 1996.

Luther III, G. W., Sundby, B., Lewis, B. L., Brendel, P. J., and Silverberg, N.: Interactions of manganese with the nitrogen cycle: Alternative pathways to dinitrogen, Geochim. Cosmochim. Acta, 61, 4043-4052, 1997. 
Lyons, T. W. and Severmann, S.: A critical look at iron paleoredox proxies: New insights from modern euxinic marine basins, Geochim. Cosmochim. Acta, 70, 5698-5722, 2006.

Macdonald, R. W. and Gobeil, C.: Manganese sources and sinks in the Arctic Ocean with reference to periodic enrichments in basin sediments, Aquat. Geochem., 18, 565-591, 2012.

Madison, A. S., Tebo, B. M., and Luther, G. W.: Simultaneous determination of soluble manganese (III), manganese (II) and total manganese in natural (pore) waters, Talanta, 84, 374-381, 2011.

Manheim, F. T.: A geochemical profile in the Baltic Sea, Geochim. Cosmochim. Acta, 25, 52-70, 1961.

Martin, J.-M. and Meybeck, M.: Elemental mass-balance of material carried by major world rivers, Mar. Chem., 7, 173-206, 1979.

Mastalerz, V., de Lange, G. J., and Dählmann, A.: Differential aerobic and anaerobic oxidation of hydrocarbon gases discharged at mud volcanoes in the Nile deep-sea fan, Geochim. Cosmochim. Acta, 73, 3849-3863, 2009.

Matthäus, W. and Franck, H.: Characteristics of major Baltic inflows - a statistical analysis, Cont. Shelf Res., 12, 1375-1400, 1992. he Nile deep-sea fan, Geochim. Cosmochim. Acta, 73, 3849-3863, 2009.

Matthäus, W. and Schinke, H.: The influence of river runoff on deep water conditions of the Baltic Sea, Hydrobiologia, 393, 1-10, 1999.

Matthäus, W., Nehring, D., Feistel, R., Nausch, G., Mohrholz, V., and Lass, H.-U.: The Inflow of Highly Saline Water into the Baltic Sea, in: State and Evolution of the Baltic Sea, 1952-2005, John Wiley \& Sons, Inc., 2008.

Meister, P., Bernasconi, S. M., Aiello, I. W., Vasconcelos, C., and McKenzie, J. A.: Depth and controls of Ca-rhodochrosite precipitation in bioturbated sediments of the Eastern Equatorial Pacific, ODP Leg 201, Site 1226 and DSDP Leg 68, Site 503, Sedimentology, 56, 1552-1568, 2009.

Mohrholz, V., Naumann, M., Nausch, G., Krüger, S., and Gräwe, U.: Fresh oxygen for the Baltic Sea - An exceptional saline inflow after a decade of stagnation, J. Mar. Syst., 148, 152-166, 2015.

Mort, H. P., Slomp, C. P., Gustafsson, B. G., and Andersen, T. J.: Phosphorus recycling and burial in Baltic Sea sediments with contrasting redox conditions, Geochim. Cosmochim. Acta, 74, 1350-1362, 2010.

Mouret, A., Anschutz, P., Lecroart, P., Chaillou, G., Hyacinthe, C., Deborde, J., Jorissen, F., Deflandre, B., Schmidt, S., and Jouanneau, J.-M.: Benthic geochemistry of manganese in the Bay of Biscay, and sediment mass accumulation rate, Geo.-Mar. Lett., 29, 133-149, 2009.

Mucci, A.: The behavior of mixed Ca-Mn carbonates in water and seawater: controls of manganese concentrations in marine porewaters, Aquat. Geochem., 10, 139-169, 2004.

Neretin, L. N., Pohl, C., Jost, G., Leipe, T., and Pollehne, F.: Manganese cycling in the Gotland Deep, Baltic Sea, Mar. Chem., 82, 125-143, 2003.

Neumann, T., Christiansen, C., Clasen, S., Emeis, K.-C., and Kunzendorf, H.: Geochemical records of salt-water inflows into the deep basins of the Baltic Sea, Cont. Shelf. Res., 17, 95-115, 1997.

Neumann, T., Heiser, U., Leosson, M. A., and Kersten, M.: Early diagenetic processes during Mn-carbonate formation: Evidence from the isotopic composition of authigenic Ca-rhodochrosites of the Baltic Sea, Geochim. Cosmochim. Acta, 66, 867-879, 2002.

O'Sullivan, T. D. and Smith, N. O.: Solubility and partial molar volume of nitrogen and methane in water and in aqueous sodium chloride from 50 to $125^{\circ}$ and 100 to 600 atm, J. Phys. Chem., 74 , 1460-1466, 1970.

Pakhomova, S. and Yakushev, E. V.: Manganese and Iron at the Redox Interfaces in the Black Sea, the Baltic Sea, and the Oslo Fjord. In: Chemical Structure of Pelagic Redox Interfaces, Yakushev, E. V. (Ed.), The Handbook of Environmental Chemistry, Springer Berlin Heidelberg, 2013.

Pakhomova, S. V., Hall, P. O., Kononets, M. Y., Rozanov, A. G., Tengberg, A., and Vershinin, A. V.: Fluxes of iron and manganese across the sediment-water interface under various redox conditions, Mar. Chem., 107, 319-331, 2007.

Parkhurst, D. L. and Appelo, C.: User's guide to PHREEQC (Version 2): A computer program for speciation, batch-reaction, onedimensional transport, and inverse geochemical calculations, US Geological Survey Water-Resources Investigations Report 994259, 312 pp., 1999.

Passier, H. F., Böttcher, M. E., and de Lange, G. J.: Sulphur enrichment in organic matter of eastern mediterranean sapropels: A study of sulphur isotope partitioning, Aquat. Geochem., 5, 99 118,1999

Pohl, C. and Hennings, U.: The coupling of long-term trace metal trends to internal trace metal fluxes at the oxic-anoxic interface in the Gotland Basin $\left(57^{\circ} 19,20^{\prime} \mathrm{N} ; 20^{\circ} 03,00^{\prime}\right.$ E) Baltic Sea, J. Mar. Syst., 56, 207-225, 2005.

Rickard, D.: The solubility of FeS, Geochim. Cosmochim. Acta, 70, 5779-5789, 2006.

Riley, J. P.: The Spectrophotometric Determination of Ammonia in Natural Waters with Particular Reference to Sea-Water, Anal. Chim. Acta, 9, 575-589, 1953.

Savchuk, O. P., Wulff, F., Hille, S., Humborg, C., and Pollehne, F.: The Baltic Sea a century ago - a reconstruction from model simulations, verified by observations, J. Mar. Syst., 74, 485-494, 2008.

Scholz, F., McManus, J., and Sommer, S.: The manganese and iron shuttle in a modern euxinic basin and implications for molybdenum cycling at euxinic ocean margins, Chem. Geol., 355, 56-68, 2013.

Scholz, F., McManus, J., Mix, A. C., Hensen, C., and Schneider, R. R.: The impact of ocean deoxygenation on iron release from continental margin sediments, Nat. Geosci., 7, 433-437, 2014.

Slomp, C. P., Malschaert, J. F. P., Lohse, L., and Van Raaphorst, W.: Iron and manganese cycling in different sedimentary environments on the North Sea continental margin, Cont. Shelf Res., 17, 1083-1117, 1997.

Soetaert, K. and Meysman, F.: Reactive transport in aquatic ecosystems: Rapid model prototyping in the open source software R, Environ. Modell. Software, 32, 49-60, 2012.

Soetaert, K., Petzoldt, T., and Meysman, F.: Marelac: Tools for aquatic sciences, R Package Version 2.1.3. 2010.

Sternbeck, J. and Sohlenius, G.: Authigenic sulfide and carbonate mineral formation in Holocene sediments of the Baltic Sea, Chem. Geol., 135, 55-73, 1997.

Strickland, J. D. H. and Parsons, T. R.: A practical handbook of seawater analysis, Fisheries Research Board of Canada, Ottawa, Canada, 1972. 
Suess, E.: Mineral phases formed in anoxic sediments by microbial decomposition of organic matter, Geochim. Cosmochim. Acta, 43, 339-352, 1979.

Sundby, B., Silverberg, N., and Chesselet, R.: Pathways of manganese in an open estuarine system, Geochim. Cosmochim. Acta, 45, 293-307, 1981.

Turnewitsch, R. and Pohl, C.: An estimate of the efficiency of the iron-and manganese-driven dissolved inorganic phosphorus trap at an oxic/euxinic water column redoxcline, Global Biogeochem. Cy., 24, GB4025, doi:10.1029/2010GB003820, 2010.

Ulfsbo, A., Hulth, S., and Anderson, L. G.: pH and biogeochemical processes in the Gotland Basin of the Baltic Sea, Mar. Chem., 127, 20-30, 2011.

van Santvoort, P. J. M., De Lange, G. J., Thomson, J., Colley, S., Meysman, F. J. R., and Slomp, C. P.: Oxidation and origin of organic matter in surficial eastern mediterranean hemipelagic sediments, Aquat. Geochem., 8, 153-175, 2002.
Wang, Y. and Van Cappellen, P.: A multicomponent reactive transport model of early diagenesis: Application to redox cycling in coastal marine sediments, Geochim. Cosmochim. Acta, 60, 2993-3014, 1996.

Yakushev, E. V., Kuznetsov, I. S., Podymov, O. I., Burchard, H., Neumann, T., and Pollehne, F.: Modeling the influence of oxygenated inflows on the biogeochemical structure of the Gotland Sea, central Baltic Sea: Changes in the distribution of manganese, Comput. Geosci., 37, 398-409, 2011.

Yeats, P., Sundby, B., and Bewers, J.: Manganese recycling in coastal waters, Mar. Chem., 8, 43-55, 1979.

Ziegler, M., Jilbert, T., de Lange, G. J., Lourens, L. J., and Reichart, G. J.: Bromine counts from XRF scanning as an estimate of the marine organic carbon content of sediment cores, Geochem. Geophys. Geosys., 9, Q05009, doi:10.1029/2007GC001932, 2008.

Zillén, L., Lenz, C., and Jilbert, T.: Stable lead $(\mathrm{Pb})$ isotopes and concentrations - A useful independent dating tool for Baltic Sea sediments, Quat. Geochronol., 8, 41-45, 2012. 